Historic, Archive Document

Do not assume content reflects current scientific knowledge, policies, or practices. 


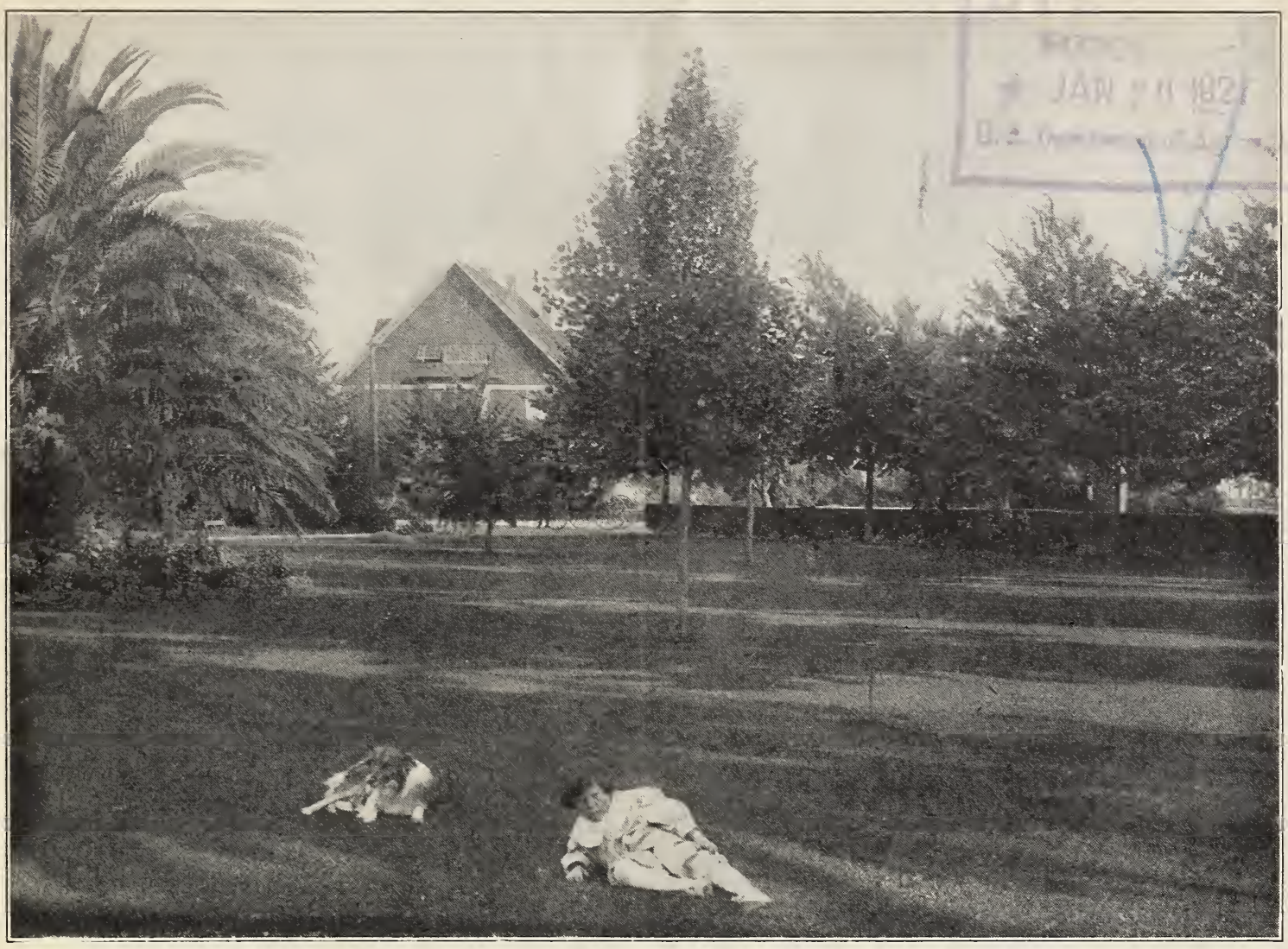

อิจ

GT:

THE VALLANCE NURSERY 81 GLEN AVENUE

AT 40TH ST. AND PIEDMONT AVE. KEY ROUTE STATION

OAKLAND, CALIFORNIA

TELEPHONE PIEDMONT 30

अलाभ?

Supplying C. C. Morse E Co, 648 Market St., San Francisco, with Trees and Plants 


\section{THE VALLANCE NURSERY}

\section{GREENHOUSES and SALESYARD are situated on GLEN AVENUE, off Piedmont Avenue, OAKLAND, CALIF.}

\section{Visitors from San Francisco can reach there by taking the Key Route Ferry (foot of Market Street) to Piedmont Avenue Station; those from Oakland, by taking the A or B cars on Broadway to Glen Avenue. Telephone, PIEDMONT 30. \\ ORDERS. Customers will please remember that when the busy season commences the Nursery is rushed with orders, and it may be a few days before their orders can receive attention; but they may rest assured that there will be no unnecessary delay in shipping.}

Prices quoted herein are f. o. b. cars, Nurseries, and cancel all previous quotations. As usual, 5 will be furnished at 10 rates; 50 at 100 rates.

CLAIMS. Should any errors occur we desire to be inform sd upon receipt of goods, in order that we may rectify them without delay. All claims must be flled within ten days after the arrival of the shipments.

THE VALLANCE NURSERY give no warranty, express or implied, as to description, purity, productiveness, or any other matter of any seeds, plants or trees they send out, and will be in no way responsible for the crop. "If the purchaser does not accept the goods on these terms they are at once to be returned.

PACKING. Sufficient money should be added to remittance to cover cost of boxing, etc. Say 10 per cent of purchase.

SUBSTITUTION. Where particular varieties are ordered, and particular ages and sizes of trees, kinds of stock, etc., it should be stated whether and to what extent substitution will be allowed in case the order cannot be filled to the letter. Where no instructions in this respect accompany the order, we shall feel at liberty to substitute other varieties as nearly similar as possible. If the selection of varieties is left entirely to us we shall endeavor to send only such sorts as are acknowledged to give general satisfaction.

GUARANTEE. We do not guarantee stock to live, nor will we replace free of cost that which dies or fails to grow. We do guarantee, however, that all Nursery stock will be in good, live and healthy condition upon departure from the Nursery.

Landscape and Orchard Department. We will be pleased to give advice to those who contemplate planting orchards. Thirty years' experience in this State in both departments enables us to do this.

\section{CULTURE OF THE ROSE}

\section{PI.ANTING}

January, February and March are the best months, but should the season be favorable, and with a little extra care, you can still plant during the early part of April. The plants sent during those months are what we call dormant two-year-old plants, and average from one and a half to two and a half feet in height, and are taken up without soil around the roots. Should the purchaser be unable to plant them immediately, they will take no harm to remain in the packing for a few days, or they can be orened up and "heeled" in the ground until ready to set out. The bushes sent out are already pruned. Our plants are budded on the wild root; by so doing we can get a strong root for the rose; our "stocks", are always disbudded, but it sometimes happens that a sucker grows from the root; planters should be careful to keep all suckers (if any), from BELOW the bud, cut away, otherwise the stock outgrows the rosebud itself.

Roses give the best results when planted in good, heavy soil, to which may be added some good old stable manure, but remember that it ought to be well decayed. After the hole is about threequarters filled with soil, give some water to settle the earth around the roots; then put the remaining soil into the hole. This is usually enough water to give during the winter, provided we have not a long, dry period; in that case the plants should get another watering at regular intervals. They will commence to bloom the first season after planting. in May and June, and if properly treated, will give an abundance of flowers the first season. After the blooms are past, we advise you to cut the old flowers off; this treatment induces them to make new growth, from which you will obtain your next crop. To aid them at that time, keep them freely watered, and by so doing you can have flowers away into December.

\section{PRUNING}

A few remarks on this important point are now necessary. This should be done during the months of January and February; at that time the bushes are in a dormant condition. Cut back to about six or seven inches from the old wood, thinning out all wea' wood and leaving about five or six shoots, according to size of plant; arply the same method that the nrchardist does to his fruit trees, and you will be about right. The idea is not to leave too much wood on the plant. If you follow this method you will have large roses with long stems. If you fail in pruning and thinning out, you will have a plethora of small blooms.

\section{SOIL AND POSITION}

There are few places in the garden where the rose will not sic. ceed. Our California soil is pre-eminently adapted for the health of the rose and sunlight we have to our heart's content: only, bear in mind, do not plant your roses in a too shady place, and if your soil is sandy, add a quantity of loam and old manure to enrich it, as the rose delights in good heavy rich soil.

\section{WATERING}

The best way to do this is to dig a ditch around vour bushes and run the water into it, afterward putting back the dry soil; by this means the water gets to the roots. Avoid surface watering, which in a great many cases never reaches the roots, and only tends to bake and harden the surface. Better one GOOD WATERING once a week than SPRINKLING them every day. Occasionally spray them overhead at night to keep the foliage free from dust. You can also give them during the summer months liquid cow manure every two or three weeks.

\section{DISEASES}

You must not expect in the genial climate of California to have your roses entirely free from insects, but they are few and easily controlled.

APHIS, or GREEN FLY, is a small green louse, appearing on the young, tender shoots and buds. They are very prolific in breeding. Through their tender beak they suck the juices of the plants, always working at the tender shoots, and will in a short time, if unmolested, destroy the vigor and vitality of any plant they infest. REMEDIES: "Black Leaf 40 "' is the best remedy (see Insecticides).

MILDEW. When your plants become covered with a whitishlooking mould or dust, the disease is Mildew. Unless a very severe attack, it will probably not kill them, but retard their growth. It is caused, we believe, by sudden atmospheric changes and is generally worse in the spring when the nights are coid and the davs are warm. Dust them in the morning with powdered SULPHUR, or if the disease has made its appearance, syringe with a solution of suphide of potassium.

ROSE SLUG. About the size of the common house fly, and comes from the ground in early spring. The best remedies are powdered white hellebore or a solution of whale oil soap.

ROSE BUG. Is of a grayish color, and about half an inch in length. It appears suddenly in early spring, and feeds upon the opening buds and flowers, which it prefers to the foliage, and seems to be more fond of white and light-colored flowers than of the darker colored ones. The best and really oniy cure is handpicking.

From the above, it will be noticed that the enemies of the rose are few, and really the only one which is at all troublesome is the Green Fly.

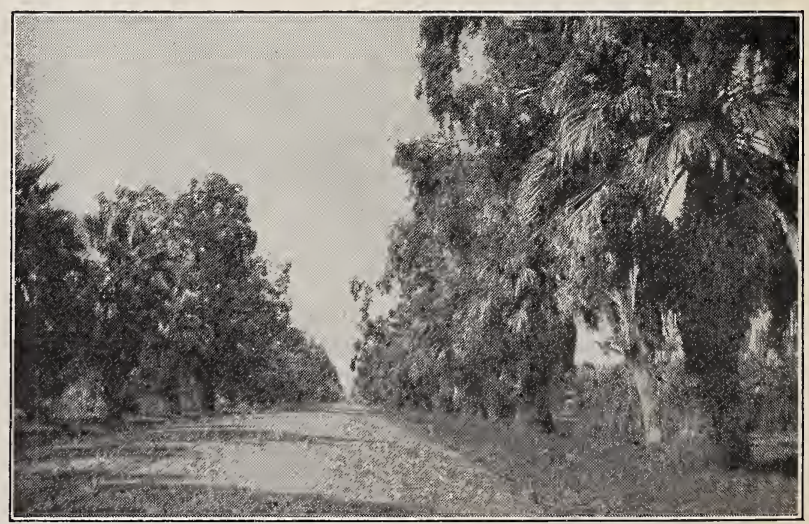

We should have more of our California Roads planted in this manner. 


\section{ROSES OF GREAT MERIT}

75 c each, $\$ 7.50$ per dozen.

Except where noted otherwise, 2 year, fleld grown.

\section{AUTUIMN TINTS}

Coppery red, shaded orange and salmon, of very great excellence.

\section{BELLE OF PORTUGAL}

A vigorous climber, flowers lovely silvery pink, of large size. Very desirable.

\section{BILLARD ET BARRE}

Clear canary yellow; buds and flowers large cupped shaped. This is an unique shade, and is of great merit.

\section{CANDEUR LYONNAISE}

A vigorous grower, flowers white, large, and freely produced.

\section{CHARLES K. DOUGLAS}

Intense flaming scarlet, flushed bright velvety crimson; a flower of great brilliance and charm; very free bloomer.

\section{CHATILLON ROSE}

A perfect miniature rose. Flowers medium size, semidouble, bright pink pointed buds. Excellent for pot culture.

\section{CHEERF'UL}

Pure orange-flame, with distinct orange-yellow base; lovely in every way.

\section{CLIMBING GENERAL McARTHUR}

A strong growing variety of the old favorite; dazzling crimson-scarlet.

\section{CLIMBING HOOSIER BEAUTY}

Rich velvety crimson, which does not fade; buds are long and pointed.

\section{CLIMBING LADY HILLINGDON}

Flowers large and loose with long, pointed buds and large petals, color a deep apricot yellow, assuming a deeper shade when fully open; growth strong and vigorous; foliage when young dark purple changing to deep green with a violet hue with age at maturity. $\$ 1.00$ each.

\section{CLIMBING MRS. AARON WARD}

Yellow, tinted salmon rose. Color variable. In spring it is nearly white outside, with blush of light salmon center. In the fall the color deepens to a good yellow.

\section{CLIMBING PAUL'S SCARLET}

Clear bright scarlet; very free blooming; of strong habit.

\section{CLIMBING SUNBURST}

Rich yellow, shaded with orange and copper; a strong vigorous grower.

\section{CLIMBING YELLOW CECILE BRUNER}

A lovely yellow variety of the old favorite Cecile Bruner.

\section{COLUMBIA}

Flowers a handsome shade of pink, deepening as they open to a glowing pink, and produced on long, stiff stems, fragrant; a free grower producing long stems with the foliage evenly distributed.

\section{CONSTANCE}

Orange-yellow buds, sometimes streaked crimson; changing to golden yellow as the flowers open. Very beautiful.

\section{CRUSADER}

This new introduction of American origin breathes character, stability and boldness in every line. Its growth is sturdy, its canes erect, its foliage heavy, its flowers are large with petals nicely reflexed at the edges; color a rich velvety crimson

\section{DUCHESS OF WELLINGTON}

Intense saffron yellow; a very beautiful color; buds long and pointed; exceedingly free in binom.

\section{GOLDEN EMIBLEIM}

Flowers of clear yellow, showing buds with a tinge of delicate crimson on the outer petals; borne on strong upright stems; foliage a handsome glossy green; growth free and branching, mildew proof. $\$ 1.25$ each.

\section{GOLDEN OPHELIA}

An excellent new seedling of Ophelia. The flower is of medium size, deep golden yellow in the center, paling slightly toward the outer petals; of perfect symmetrical form, and the plant is a sturdy, stiff-stemmed grower.

\section{HOOSIER BEAUTY}

Glowing crimson scarlet with darker shadings; texture like velvet; deliciously fragrant. The buds are long and pointed, borne on long stiff stems.

\section{HADLEY}

Dark velvety crimson; very fragrant.

\section{H. V. MACHIN}

Flowers an intense, dark grained, scarlet crimson.

\section{IRISH ELEGANCE}

Apricot shaded coppery bronze. Single.

\section{IRISH FIREFLAME}

old gold; flushed crimson; buds long and nointed: poliage rich and glossy; plant strong grower. A very charming single rose.

\section{ISOBEL}

This lovely acquisition to the single roses will surely be welcomed by all rose lovers. It is an exquisite shade of pink flushed orange scarlet.

\section{JULIET}

Outside of petals old gold, center rich, rosy red, changing to deep rose as the flowers expand.

K. OF $\mathrm{K}$.

Semi-double with large petals, intense scarlet; free bloomer, sweetly scented.

\section{LADY HILLINGDON}

Blooms continuously, buds very long with a most pleasing shade of orange yellow. Particularly flne in the bud state.

\section{LOS ANGELES}

The originator (Fred S. Howard) describes Los Angeles as "a flame pink, toned with coral and shaded with translucent gold at the base of the petals.'

\section{LOUISE-CATHERINE BRESLAU}

Flowers shrimp pink, shaded with orange and chrome yellow, large, full and globular; a vigorous climbing sport of the bush form, considered a valuable acquisition to this class of roses.

\section{I.YON ROSE}

One of the judges who awarded the gold medal to this rose says: "I have no hesitation in recommending it as the most wonderful color yet obtained among roses. This may be best compared to the intense flame color seen in a glowing coke furnace."

\section{MADAIIE BUTTERFLY}

Brilliant pink suffused apricot and gold; flowers carried on long stems. A very flne acquisition to our newer roses.

\section{MADAME MELANIE SOUPERT}

Salmon yellow, suffused carmine; buds long and pointed; when open the flowers resemble a semi-double paeony.

\section{MADAMIE HERRIOT}

"Daily Mail Rose"

Coral red, shaded yellow at base, passing to shrimp red; a very beautiful combination of colors.

\section{MIME. COLETTE MARTINET}

A vigorous growing variety; long golden-yellow bud opening to a beautiful old-gold, shaded with orange-yellow; attractive bronzy-green foliage.

\section{MRS, C. W BULLER}

Rosy carmine; large, well formed flowers, freely and continuously produced.

\section{IMRS. HENRY BOWLES}

Flowers bright rose tinged with clear vermilion veining on petals, flne in size and substance, of good form and sweetly scented; a good all around variety. \$1.00 each.

\section{MRS. WEMYSS QUINN}

Intense lemon-crome, suffused orange, which gives it a rare depth of color, which never fades out; flowers and buds ideal; long bloomer: habit of growth perfect.

\section{IMRS. AMBROSE RICCARDO}

Varying in color from a deep honey-yellow with soft but glowing rosy suffusion to a soft saffron-yellow.

\section{MRS. S. K. RINDGE}

Buds are long and pointed and carried erect on stiff stems Color, clear rich chrome-yellow, becoming suffused with salmon-pink as the flowers mature. The flowers are of good size and moderately double and are produced freely. 


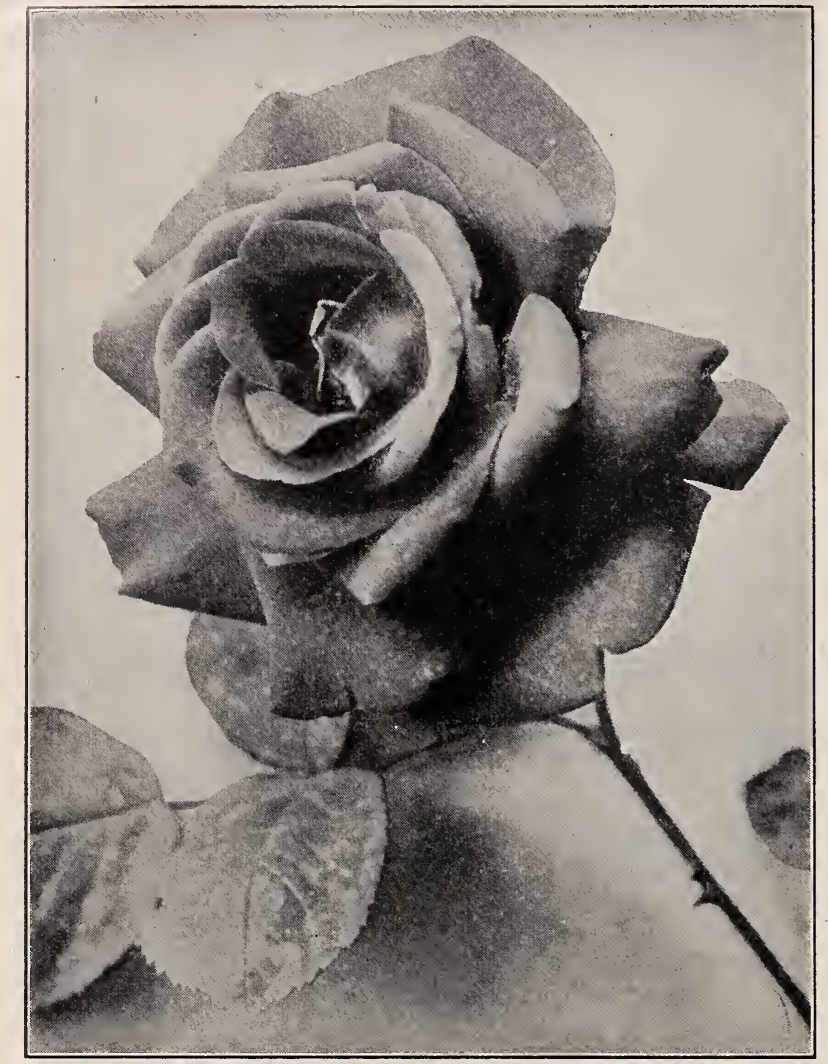

General MacArthur

\section{MRS. E. C. VAN ROSSEM}

Velvety crimson heavily veined dark maroon; flowers produced during many months in the year in great profusion. A most satisfactory variety and one that will be a "standby". $\$ 1.00$ each.

\section{MIRS. H. STEVENS}

A grand pure white; buds and flowers exquisite, which are produced for a long period in great profusion. Highly commended.

\section{MARECHAL NIEL}

Deep yellow, large globular form; a good pillar rose.

\section{OPHELIA}

Salmon flesh, shaded rose, center of flower showing pronounced coloring of chamois; buds long and pointed; very free in bloom.

\section{PREMIER}

Pure rose-pink, borne on stiff thornless stenıs; deliciously Pragrant; very free in bloom.

\section{QUEEN MARY}

Creamy ground, pencilled and flushed carmine, with an underlying shade of yellow; a wonderful combination of colors; it is extremely free in bloom; of dwarflsh habit, thus making it a fine sort for bedding purposes.

\section{STAR OF PERSIA}

Semi-double, bright yellow flowers, borne in long sprays; color does not fade, and the flower trusses last several weeks. A splendid acquisition to our climbers. $\$ 1.00$ each.

\section{WILLOWMERE}

Rich shrimp-pink, shaded at center with yellow, edged rosy carmine; a very lovely variety.

\section{WM. F. DREER}

Flowers a soft, silvery shell pink, base of petals a rich golden ellow, especially beautiful in all stages of development; foliage bust and unique, growth vigorous and free flowering; a good rden rose.

\section{ROSES, FINE ASSORTMENT}

\section{$65 \mathrm{c}$ each; $\$ 6.50$ per dozen.}

Please state if we can substitute if sold out of any varieties ordered.

AMERICAN BEAUTY-Large, globular, deep pink, shaded carmine, delicious odor.

AMERICAN PILLAR-Flowers a lovely shade of pink with a clear white eye and bright yellow stamens, blooms large and single, produced in huge clusters, very effective.

ARTHUR R. GOODWIN-Apricot flushed salmon, fading to shrimp pink; a very lovely sort.

BEAUTY OF GLAZENWOOD-A combination of copper, carmine and salmon-yellow; a strong, fast climber.

BETTY - Coppery rose overlaid with ruddy gold; bud's long and pointed.

CAROLINE TESTOUT-Bright, clear, delicate pink.

CECILE BRUNER-A charming "Baby" variety; color salmonpink, with deep salmon center.

CHEROKEE-Pink.

CLEVELAND-Deep coppery yellow at base of petals; flushed reddish copper. Exquisite shape, and free bloomer.

CLIMBING BELLE SIEBRECHT-A climbing sort of the old favorite bush variety; buds long and pointed; beautiful shade of pink.

CLIMBING CAROLINE TESTOUT-An exact counterpart in color and shape of that old favorite, Caroline Testout.

CLIMBING CECILE BRUNER-Same as that of the bush form in all respects.

CLIMBING LADY ASHTON-Glistening pink; buds and full blown flower excellent.

CLIMBING PAPA GONTIER-Rosy crimson with carmine center. All that its name implies. Flowers identical with the bush variety except that they are somewhat larger.

CLIMBING REVE D'OR-Deep yellow; foliage ideal; strong and vigorous.

ClIMBING VICTORIA-Buds long and pointed; pure white.

CLIMBING W. A. RICHARDSON-Deep orange-yellow.

EXCELSA-A fine red cluster sort; excellent for arches or pillars.

F. K. DRUSCHKI (White American Beauty)-Pure snow-white; very long buds; shell-shaped petals.

GENERAL MCARTHUR-Dazzling crimson scarlet; buds of ideal shape and exquisite perfume; foliage beautiful; a strong, thrifty grower.

GEORGE ARENDS - Delicate pink. A large, handsome rose of solid color and good form. Widely heralded as "Pink Frau Karl Druschki" but does not look like a sport from that variety.

GRUSS AN TEPLITZ-Rich scarlet, overlaid with crimson, particularly in spring. The ground color is intensely red, unsurpassed by any other.

HIAWATHA-Brilliant scarlet, single flowering in large clusters: climber.

HUGH DickSON-A brilliant velvety crimson shaded scarlet; bud long and pointed.

K. A. VICTORIA-Full flowers; magniflcent in bud; stems long; pure white.

LA FRANCE-Delicate silvery rose, shaded with cerise pink, often silvery pink, with peach shading.

LAURENT CARLE-Brilliant, velvety carmine; flowers large, of perfect form and delightful fragrance; a good grower and abundant free bloomer. A wonderful bedding rose.

MRS. A. R. WADDELL_Color reddish salmon, outer petals flesh; buds and petals long; flowers of medium size and semi-double. A fine flowering sort, of good upright semi-double.

MRS. AARON WARD-Distinct shade of apricot-yellow shading lighter toward the edges. Very free flowering.

MRS. CHARLES RUSSELL_-Brilliant rosy carmine with scarlet center; flowers beautifully formed and borne on strong stems.

MRS. W. CHRISTIE MILLER-Rosy carmine; outer petals pearly blush; buds and flowers very large.

MAMAN COCHET PINK-Deep pink; buds long and pointed, of great substance; a continuous bloomer.

MAMAN COCHET WHITE-Buds faintly suffused with pink on outside petals; foliage glossy.

PAPA GONTIER-Dark cherry-red; buds long and pointed; very free grower and good bloomer.

PAUL NEYRON-Clear pink; one of the largest roses grown.

PERLE D'OR-Salmon pink shaded rose; flowers in clusters; a very pretty "Baby" rose.

RADIANCE-Brilliant rosy carmine; large and full flowers of beautiful shape. 
RAYON d'OR-Flowers large of globular form; color golden yellow tinged coppery orange; foliage beautiful; a grand sort.

RICHMOND-Vivid scarlet; free bloomer; flne.

SILVER MOON-A strong rapid grower; foliage dark and glossy; flowers in clusters in spring and early summer; creamy white; semi-double.

SUNBURST-A magniflcent yellow, shaded orange copper; long buds on strong stems; flowers are large. A vigorous and healthy grower.

THOUSAND FLOWERS-This cluster rose is a most charming variety, its delicately colored pink flowers are most attractive; makes a grand porch or pillar plant.

ULRICH BRUNER-Bright, clear red; a profuse bloomer and hardy grower.

\section{STANDARD ROSES}

We can supply roses in standard or tree form; that is, they are budded on single stems, four to four and one-half feet from the ground. \$2.00 each.

\section{MORSE'S COLLECTIONS OF DAHLIAS}

HOME GARDEN COLLECTION-Twelve good varieties, assorted types and colors. Our selection; $\$ \mathbf{5 . 0 0}$.

SPECIAL COLLECTION-A collection of twelve Dahlias. Assorted types and colors; $\$ \mathbf{\$ 7 . 5 0}$.

POMPON COLLECTION-Twelve assorted Pompon Dahlias. Each bulb different and all named and tagged; $\$ 3.50$.

DECORATIVE COLLECTION-A collection of twelve California Decoratives, containing one each of the following. All for $\$ 8.00$.
Amun Ra

Black Jack

Champagne

Dr. Tevis
Mrs. I. De Ver Warner Mrs. Richard Lohrman Pride of California Princess Pat
UNION JACK-The most striking single Dahlia in existence. Petals are white, each one being regularly edged with vivid scarlet. Splendid for cutting; each 50c.

\section{SPRING PLANTING BULBS}

MORSE'S SPECIAL MIXED GLADIOLUS-This mixture is made up of the choicest named varieties, including the above varieties. This contains a wide range of colors and the newer shades. Price \$1.00 per dozen; \$7.00 per 100.

MORSE'S BEDDING MIXED GLADIOLUS - An assortment of good varieties, in well-balanced colors. This mixture is especially adapted for massing and bedding. Price $\mathbf{7 5 c}$ per dozen; $\$ 5.00$ per 100.

GLADIOLUS PRIMULINUS HYBRIDS-This type of Gladiola is becoming very popular. Unlike the ordinary variety, the petals are quite thin and the individual flowers are spaced on the stem, which gives them an attractive appearance. We carry the Primulinus Hybrid type in mixed colors only, and if planted this way, in perennial borders, among shrubbery, or massed in beds, they will give great satisfaction. Prices: Per doz, 75c; per 100, \$5.00.

LILY OF THE VALLEY - The pure white fragrant flowers and pale green foliage of this plant, render it one of the most beautiful and most admired. They succeed well in any soil, but prefer a sandy location.

Price, 75c per doz.; postpaid 85c; $\$ 5.50$ per 100 , postpaid.
MORSE'S YELLOW CALLA LILY-Morse's Yellow Calla Lilie are beautiful for bedding or pot culture. Easy to grow and very free blooming. If grown in pots, will make flne house plants.

MAMMOTH BULBS-Produce large blossoms. Each 25c; per doz. \$2.50; per $100 \$ 17.50$.

CALADIUMS are large-leaf plants with-

$$
\text { Each Postpaid Doz. }
$$
out flowers, which give a tropical appearance to the home garden. They are most effective for unsightly corners, etc........ \$0.30 5c extra by mail.

BEGONIAS - Single Fringed Hixed.... $.30 \quad .35 \quad 3.00$ BEGONIA-Double Vixed $-35 \quad 30 \quad 3.50$ BEGONIA-Single Mixed $\ldots \ldots \ldots \ldots \ldots . .25 \quad .30 \quad 2.50$

TUBERoses - The Pearl Each Dozen 100

HYACINTHS-Candicans. Summer Hya- $\$$ cinths .................... $25 \quad 2.50 \quad 17.50$

GLOXINIAS-lixed .............. $3.50 \quad 25.00$

\section{HARDY EVERGREEN TREES}

Potted plants are taken from pots when shipped.

"Balled" means the plants are taken from the ground with a ball of soil around the roots.

\section{ACACIA}

For quick growth and shade-affording purposes we know of no better tree. We offer the following varieties, all potgrown.

ARMATA-1 $1 \frac{1}{2}$ to 2 feet, $50 \mathrm{c}$ each; $\$ 4.00$ per 10.

BAILEYANA-Beautiful silvery foliage, producing long grapelike clusters of sweetly scented flowers. 24 to $\mathbf{3 0}$ inches, $\$ 1.25$ each.

CULTRIFORMIS. Foliage of this variety is triangular in form; color beautiful sea-green; profuse in bloom; of medium sized spreading growth. 3 to $31 / 2$ feet, $75 \mathrm{c}$ each; $\$ \mathbf{6 . 0 0}$ per 10.

CYANOPHYLLA (Blue-Leaved Wattle). Flowers yellow, leaves very large; glaucous green. 3 to 4 feet, $60 \mathrm{c}$ each; $\$ 5.00$ per 10.

DEALBATA (Mollissima). One of the finest of the feathery foliaged, yellow flowering sorts. 12 to 15 inches, $30 \mathrm{c}$ each; $\$ 2.50$ per $10 ; 18$ to 24 inches, $50 \mathrm{c}$ each; 4 to 5 feet, $\$ 1.00$ each.

LATIFOLIA. This variety is much used for windbreaks; it is excellent for sidewalk planting, as it can be trimmed to any desired shape. 3 to 4 feet, $60 \mathrm{c}$ each; $\$ 5.00$ per 10;

MELANOXYLON (Blackwood Tree). A splendid sort for sidewalk planting; of very quick growth. $31 / 2$ feet, $40 \mathrm{c}$ each; 4 to $41 / 2,60$ c each; 5 to 6 feet, $\$ 1.00$ each.

PYCNANTHA. Medium in growth; leaves very large; flowers beautiful yellow. $1 \frac{1}{2}$ to 2 feet, $30 \mathrm{c}$ each.

RETINOIDES FLORABUNDA. Pendulous habit; sea-green foliage; very fioriferous and sweet perfumed. 3 to 4 feet, $60 \mathrm{c}$ each; $\$ 5.00$ per $10 ; 5$ to 6 feet, $\$ 1.00$ each.

VERTICILATA. 2 to 3 feet, $75 \mathrm{c}$ each.

CALIForNia Big TREe (Sequoia Gigantea). $11 / 2$ feet, $\$ 1.50$ each.

CALIFORNIA PRIVET. See Ligustrum Ovalifolium.
CALIFORNIA REDWOOD. See Redwood.

CAMPHOR TREE. A fast-growing, very symmetrical, ornamental tree, thriving in the very poorest soil. Well adapted for lawn purposes. Pot grown, 11/2 feet, $\$ \mathbf{1 . 0 0}$ each.

CALIFORNIA WILD CHERRY. Beautiful glossy foliage; berries black. 5-inch pots, $\$ 1.00$ each.

CAROB TREE (St. John's Bread). 4-inch pots, $40 \mathrm{c}$ each.

CASUARINA STRICTA. 4-inch pots, 40c each; $\$ 3.50$ per 10. Balled, 3 to 4 feet, $\$ 1.50$ each.

CEDRUS DEODARA, Indian or Himalayan Cedar. One of the handsomest of coniferous trees. From $\$ 5.00$ to $\$ 6.00$ each.

\section{CYPRESS}

ARIzONA. Foliage sea-green, pyramidal in shape; beautiful. Balled, 15 to 18 inches, $50 \mathrm{c}$ each; 3 to 4 feet, $\$ 3.50$ each.

LAWSON SILVER. It is of rather upright growth; the branches droop gracefully, and the foliage is of a lovely sea-green color. 18 inches, $\$ 1.50$ each.

MONTEREY. A native of California, and one of the most desirable of evergreens; stands pruning well; very extensively planted for hedges. Transplanted in flats, $\$ 4.00$ per flat (of about 100). Pot grown, 10 to 15 inches, 25c each; $\$ 2.00$ per $10 ; 3$ to 4 feet, $\$ 1.00$ each; $\$ 9.00$ per 10. Balled, 15 to 18 inches, $60 \mathrm{c}$ each; $\$ 5.00$ per 10 ; 5 to 6 feet, $\$ 4.00$ each.

ITALIAN. Of upright, pyramidal growth; very much used in landscaping, being particularly adapted for such work. Balled, 18 to 24 inches, $\$ 1.25$ each; 2 to $21 / 2$ feet, $\$ 2.00$ each; 3 to $31 / 2$ feet, $\$ 3.00$ each; 4 to $41 / 2$ feet, $\$ 4.00$ each.

EDWARDSIA. Foliage delicate, flowers yellow. 4-inch pots, 40c each. 


\section{HARDY EVERGREEN TREES-Continued.}

\section{EUCALYPTUS}

CORYNOCALX SUGAR GUM. Pot grown, 15 to 18 inches, 25c each; $\$ 2.00$ per 10.

FICIFOLIA, Scarlet-flowerIng Gum. A beautiful sort; bearing lovely scarlet flowers, thick leathery leaves; hardy only in warmer sections. 10 to 12 inches, 50c each; $21 / 2$ to 3 feet, $\$ 1.50$ each.

GLOBULUS, Tasmanian Blue Gum. Transplanted In flats, $\$ 3.50$ per $100 ; 2$ to $21 / 2$ feet, $30 \mathrm{c}$ each; $\$ 2.50$ per $10 ; 3$ to $31 / 2$ feet, $40 \mathrm{c}$ each; $\$ 3.50$ per $10 ; 4$ to 5 feet, $60 \mathrm{c}$ each; $\$ 5.00$ per 10.

POLyanthema. Pot grown, 15 to 18 inches, 25c each; $\$ 2.00$ per 10.

ROSTRATA, Red Gum. In flats, $\$ 3.50$ per $100 ; 4$-inch pots, 30c each; $\$ 2.50$ per 10.

GREVILLEA ROBUSTA, Australian silk Oak. A most beautiful Australian tree; feathery foliage; orange-yellow blossoms. 4-inch pots, 40c each; $\$ 3.50$ per 10.

GREVILLEA THELMANIANA. Flowers pink; pretty shrub. \$1.00 each.

JUNIPER BERMUDA. Upright habit; foliage bright green. Balled, $11 / 2$ to 2 feet, $\$ 1.50$ each.

JUNIPER CREEPING. Dwarf spreading habit. $\$ 1.50$ and $\$ 2.50$ each.

JUNIPER, Irish. Of Inright pyramidal growth; glaucous foliage. $11 / 2$ feet, $\$ 1.50$.

LAUREL, PORTUGAL.. A handsome shrub; foliage dark-green; long panicaled pure white flowers. Balled, $1 \frac{1}{2}$ to 2 feet, bushy, \$2.50 each.

LIGUSTRUM. See Privet.
LOQUAT. Balled, $\$ 1.50, \$ 2.00$ and $\$ 2.50$ each.

PEFPER TREE. 10 to 12 inches, 25c each; $\$ 2.00$ per $10 ; 18$ inches, 60c each; $\$ 5.00$ per 10.

PINE, MONTEREY. Balled, 15 to 18 inches, $50 \mathrm{c}$ each; $\$ 4.00$ per 10; 4-inch pots, 40c each; $\$ 3.50$ per 10 .

PITTOSFORUM, CRASSIFOLIA. 5-inch pots, 50c each; $\$ 4.00$ per 10. Balled, 2 to 3 feet, $\$ 1.50$ each.

PITTOSPORUM EUGENOIDES. A large, upright-growing shrub, with glossy, yellowish green leaves; a very effective shrub and excellent for hedges. Pot grown, 2 feet, $60 \mathrm{c}$ each; $\$ 5.00$ per 10.

PITTOSPORUM, NIGRICANS. A very handsome, uprightgrowing shrub, with silvery light green leaves and black stems. 3-inch pots, 30c each; $\$ 2.00$ per 10 . Balled, $1 \frac{1}{2}$ to 2 feet, $75 \mathrm{c}$ each; $\$ 6.00$ per 10.

PITTOSPORUM, TOBIRA. White fragrant flowers; leaves very glossy. 4-inch pots, 25c each. Balled $1 \frac{1}{2}$ feet, $60 \mathrm{c}$ each; 2 to $2 \frac{1}{2}$ feet, $\$ 1.50$ each.

PITTOSPORUM, UNDULATUM. Flowers white, sweetly scented. 5-inch pots, $60 \mathrm{c}$ each.

PRIVET ELEGANTISSIMA AUREA. A variety with beautiful golden foliage. Balled, 60c, 80c, $\$ 1.00$ each, according to size.

PRIVET JAPONICUM, Japanese Privet. Leaves glossy, leathery, dark green. A large-growing shrub (or small tree). Good hedges are obtained from this variety. 4-inch pots, 40c each; $\$ 3.50$ per 10 . Balled, 12 to 15 inches, $60 \mathrm{c}$ each.

PRivet ovaliolium (California Privet). A valuable hedge plant. Naked roots, 2 to $₹$ feet, 20c each; \$1.75 per 10; $\$ 12.50$ per 100 .

REDWOOD, CALIFORNIA. 4-inch pots, 50c each. Balled, $\$ 1.50$ and $\$ 2.00$ each.

\section{HARDY EVERGREEN AND DECIDUOUS SHRUBS}

Those Plants with a Star before the names are deciduous.

ABELIA GRANDIFLORA. A very showy evergreen shrub, producing its white flowers in great profusion for a long period. 6-inch pots, $\$ 1.00$ each.

ARBOR VITAE. Balled, $21 / 2$ feet, $\$ 2.50$ each.

ARBUTUS UNEDO, "Strawberry Tree." $11 \frac{1}{2}$ to 2 feet, $\$ 1.00$ each; smaller, 35c each.

AUCUBA JAPONICA. "Gold-dust tree." Very fine for shady places. 6-inch pots, $\$ 1.25$ each.

AUCUBA VIRDIS. Dark green foliage; produces very showy red berries. 5-inch pots, 60c each.

AZARA MICROPHYLLA. Foliage "fern-like"; flowers yellow. 2 to $21 / 2$ feet, $\$ 1.50$ each.

BERBERIS WILSONII. Extremely handsome and showy. 5-inch pots, $\$ 1.50$ each.

BERBERIS DARWINII. A very handsome evergreen shrub, with small glossy foliage; flowers in clusters of a deep yellow. $\$ 1.00$ and $\$ 1.50$ each.

BOX, DWARF, Suffruticosa. A fine small bush, with glossy, roundish leaves. The variety so extensively used for edging. Strong, well rooted. $\$ 6.00$ per 100.

BOX, JAPANESE. Good for trimming. 12 to 18 inches, $\$ 1.00$ each.

BROOM, SCOTCH. 18 to 24 inches, 80c each.

BROOM, SPANISH. 12 to 15 inches, $40 \mathrm{c}$ each; $\$ 3.50$ per 10; 2 to $2 \frac{1}{2}$ feet, $80 \mathrm{c}$ each.

CASSIA TOMENTOSA. 5 -inch pots, $2 \frac{1}{2}$ feet, $50 \mathrm{c}$ each.

CHOISYA TERNATA. "Mexican Orange." A medium-sized growing shrub with glossy foliage; flowers pure white; delightfully fragrant. Balled, $1 \frac{1}{2}$ feet, $\$ 1.50$ each.

COPROSMA BAUERIANA. Foliage of this lovely shrub as though varnished, succeeds well in windy, exposed situations. 4-inch pots, 35c each. Balled, $\$ 1.25$ and $\$ 1.50$ each.

COTONEASTER ANGUSTIFOLIA. A fast-growing sort of upright and spreading habit; berries very freely; orange colored. 5-inch pots, $65 \mathrm{c}$ and $80 \mathrm{c}$ each. Balled, $\$ 1.00, \$ 1.50$ and $\$ 2.50$ each.

COTONEASTER HORIZONTALIS. A beautiful variety, of lowspreading growth; berries very profuse. Balled, strong, $\$ 1.25$ and $\$ 3.00$ each.
COTONEASTER NEPAULENSIS. This shrub is much esteemed; of fairly rapid, upright growth; foliage medium; berries bright red; very pleasing. $21 / 2$ feet, $\$ 1.50$ each.

COTONEASTER MICROPHYLLA. A small-leaved variety of low, spreading habit; much used in making up shrubbery; berries red. Pot grown, $75 \mathrm{c}$ to $\$ 1.00$ each. Balled, $\$ 1.50$ and $\$ 2.50$ each.

COTONEASTER FRANCHETTI. Orange-colored berries. Balled, 2 to $2 \frac{1}{2}$ feet, $\$ 1.50$ each.

COTONEASTER PANOSA. Upright growth; branches long and slender; foliage green on upper side, silvery under side; rapid grower; berries borne in great profusion. Vermillion red. 4-inch pots, $40 \mathrm{c}$ each; 5 -inch pots, $80 \mathrm{c}$ each. Balled, $\$ 2.00$, $\$ 2.50$ and $\$ 3.00$, according to size.

COTONEASTER YUNANANSIS. Of spreading habit: orange berries. 4-inch pots, $40 \mathrm{c}$ each; $\$ 3.50$ per $10 ; 24$ to 30 inches, $\$ 1.25$ each.

CRATAEgus CRENULATA. An evergreen species of the Hawthorn family. Is of dwarflsh habit, with glossy foliage, and has berries of a bright scarlet color about the size of a pea. 5-inch pots, $80 \mathrm{c}$ each. Balled, $1 \frac{1}{2}$ feet, $\$ 1.00 ; 2$ to $21 / 2$ feet, $\$ 2.00$.

CRATAEgUS LELANDII (Burning Bush). Berries orange colored. Pot grown or balled, $\$ 1.00$ and $\$ 1.50$ each.

x. B.-The Cotoneasters and Crataegus (Pyracantha) all produce beautifully colored berries in fall and winter months. All very hardy and of easy growth.

DIOSMA, ALBA (Breath of Heaven). This shrub never attains large proportions. It produces small, white star-shaped flowers in great numbers. The foliage, when bruised, emits a sweet fragrance. 5-inch pots, 80c each.

*DEUTZIA GRACILIS. Flowers white, very beautiful shrub. $11 / 2$ to 2 feet, $75 \mathrm{c}$ each.

ERICA, MEDITERRANEAN. This variety is most desirable; it produces its small wax-like flowers in wonderful profusion. Balled, $\$ 1.00$ each.

ERICA MELANTHERA. Splendid winter blooming variety; flowers rose colored. \$1.25 and $\$ 1.50$ each.

ERICA PERSOLUTA ALBA. Flowers white. 5-inch pots, 80c and $\$ 1.00$ each. 


\section{HARDY EVERGREEN AND DECIDUOUS SHRUBS-Continued.}

ESCALLONIA, RED. 75c and \$1.00 each.

ESCALLONIA, PINK. Hardy, quick-growing evergreen shrub; blooms continuously. Balled, $1 \frac{1}{2}$ to 2 feet, $\$ 1.00$ each.

ESCALLONIA, WHITE. 5-inch pots, 15 to 18 Inches, $80 \mathrm{c}$ each. Balled, 2 to $21 / 2$ feet, $\$ 2.00$ each.

EUGENIA MYRTIFOLIA. Blooms profusely; flowers creamy white; berries nurple; foliage ruddy in new growth. 5-inch pots, $75 \mathrm{c}, \$ 1.00$ and $\$ 1.25$ each.

EUONYMUS AUREA. Beautiful golden foliage. Balled, 18 to 20 inches, $\$ 1.50$ each.

EUONYMUS DUC d'ANJOU. Foliage prettily marked. golden yellow in center of leaf. Balled, 24 to 30 inches, $\$ 1.50$ each; \$9.00 per 10.

EUONYMUS, JAPONICA. Dwarf habit; fine for hedges or as single specimens. Balled, 15 to 18 inches, $\$ 1.00$ each.

EUONYMUS, SILVER. Balled, $1 \frac{1}{2}$ to $2 \mathrm{feet}, \$ 1.50 \mathrm{each}$.

GENISTA RACEMosus. This variety produces very lovely yellow blossoms in great profusion; foliage lace-like; of dwarf habit. 5-inch pots, 60c each.

GENISTA CANARIENSIS. Flowers yellow, of rapid growth. 4inch pots, 40c each.

haKeA SALIGNA. Medium-sized shrub; long slender foliage, with small clusters white flowers. 5-inch pots, 2 to $2 \frac{1}{2}$ feet, $75 c$ each.

HAKEA SUAVEOLENS. A compact tall growing shrub; leaves sharply pointed; flowers white; $21 / 2$ feet, $\$ 1.25$ each.

HEATHERS. See Erica.

HYDRANGEA HORTENSIS. This plant is a most satisfactory one, blooming as it does for such a long period; they succeed admirably when planted in a shady nlace in the garden. 35c, 60c, 75c each, according to size.

HYPERICUM FLORABUNDA. A taller growing variety; flowers yellow, smaller than those of the two following sorts; very floriferous. 5 -inch pots, $2 \frac{1}{2}$ feet, $75 \mathrm{c}$ each.

HYPERICUM MOSERIANUM. Of more shruby growth than the preceding; flowers single yellow. 70c each.

HYPERICUM CALYCINUM. Of low spreading habit, producing large single, deep yellow flowers in great profusion and for a long period; flne for covering banks or planting below trees. 30c each; $\$ 2.50$ per 10.

*KERRIA JAPONICA. Bears ball-shaped double yellow flower's in great profusion during a long period. 1 to $1 \frac{1}{2}$ feet, 75 c each.

LAURUSTINUS. A well-known winter flowering shrub of great beauty, producing an abundance of white flowers; well adapted for herlges. 5-inch pots, 60c each; $\$ 5.00$ per 10. Balled, $\$ 1.00, \$ 1.50$ and $\$ 2.00$ each.

*LEMON VERBENA. The fragrance from the foliage of this old favorite is delightfully refreshing. 5-inch pots, 75c each.

LEPTOSPERNUM LAEVIGATUM. An evergreen shrub much used in Golden Gate Park, where it succeeds to perfection. Especially adapted for windy places. 5 -inch pots, 3 to $31 / 2$ feet, 75c each; \$6.50 per 10.

LEPTOSPERNUM NICHOLSII. Of smaller habit than preceding. foliage feathery; flowers lovely pastel shades. Pot grown, $\$ 1.00$ each.

*LILAC, PURPLE. White, 2 to 3 feet, $\$ 1.00$ each. LILAC BUDDED SORTS, $\$ 1.50$ each.

LONICERA NITIDA. A handsome evergreen plant of very com. pact growth; leaves small, closely set on branches, glistening green in summer, bronzy during winter. 4-inch pots, $35 \mathrm{c}$ each: $\$ 3.00$ per 10 . 5-inch pots, 60c each. Balled, 24 to 30 inches, $\$ 1.25$ each.

*MOCK ORANGE. 3 to $4 \mathrm{feet}, 80 \mathrm{c}$ each.

MYRTLE, ENGLISH. Single white. Balled, 15 to 18 inches, $\$ 1.00$ each.

OLEANDER, SINGLE WHITE. 5-inch pots, 50c each.

PIMELEA DECUSATA. Flowers beautiful rosy pink, borne very profusely at end of stems; a charming small growingshrub. Pot grown, $\$ 1.00$ each.

POLYGALA DALMATIANA. A profuse flowering shrub, with purple pea-blossom-shaped flowers, and pretty light green foliage. 5 -inch pots, $80 \mathrm{c}$ each.
*Pomegranate, DOUble scarlet. 3 to 4 feet, $80 \mathrm{c}$ each. *QUINCE (Japanese Scarlet-Flowering). 2 to $2 \frac{1}{2}$ feet, $\$ 1.00$ each.

RAPHIOLEPIS OVATA. A low-spreading shrub, dark green leaves; good for landscaping. 4-inch pots, 40c each. Balled, 12 to 15 inches, $\$ 1.00$ each.

*SNOWBALL. This well-known shrub is known to nearly everyone; white flowers in greatest profusion in May and June. 2 to 3 feet, $\$ 1.00$ each.

*SFIRAEA FRUNIFOLA. "Bridal Wreath." 3 to 4 feet, $\$ 1.00$ each.

*SFIRAEA A. WATERER. Crimson flowers, 1 to $1 \frac{1 / 2}{2}$ feet, $60 \mathrm{c}$ each.

TOJON BERRY (California Christmas Berry). 25c, $75 \mathrm{c}$ and $\$ 1.00$ each.

VERONICA CUPRESSIODES. Balled, bushy, $75 \mathrm{c}$ and $\$ 1.50$ each.

VERONICA TRAVERSII. Of dwarf bushy habit. Balled, \$1.00 each.

VERONICA DECUSATA. Of dwarf habit; leaves closely set to. gether; flowel's large violel hlur 6-inch pots, 15 to 18 inches, $75 \mathrm{c}$ each; $\$ 6.50$ per 10 . Balled, 60c, $80 \mathrm{c}$ and $\$ 1.00$ each.

VERONICA IMPERIALIS. The finest of the species. Flowers amaranth. 5-inch pots, 15 inches, 75c each; $\$ 6.50$ per 10.

VERONICA, LIGHT BLUE. 5-inch pots, 15 to 18 inches, $75 \mathrm{c}$ each.

VERCNICA BUXIFOLIA. Balled, bushy, $\$ 1.00$ and $\$ 1.25$ each.

VERONICA GLAUCOPHYLLA. Glacous foliage; of spreading habit. \$1.00 each.

VERONICA HULKIANA. Pink flowers, 4-inch pots, 35c each; $\$ 3.00$ per 10.

*WEigilea Rosea. Much esteemed shrubs; producing lovely trumpet-shaped pink flowers. 2 to 3 feet, $75 \mathrm{c}$ each.

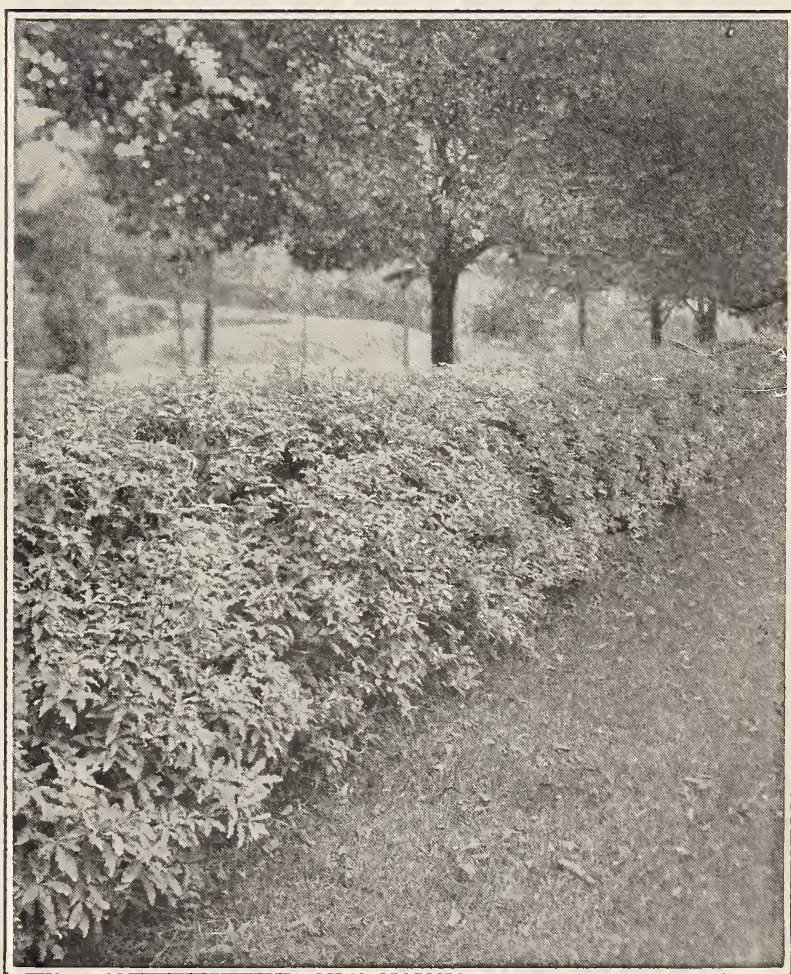

Pittosporum Hedge 


\section{PALMS, DRACAENAS}

* Marked thus are for indoor, conservatory decoration, or warmer sections only.

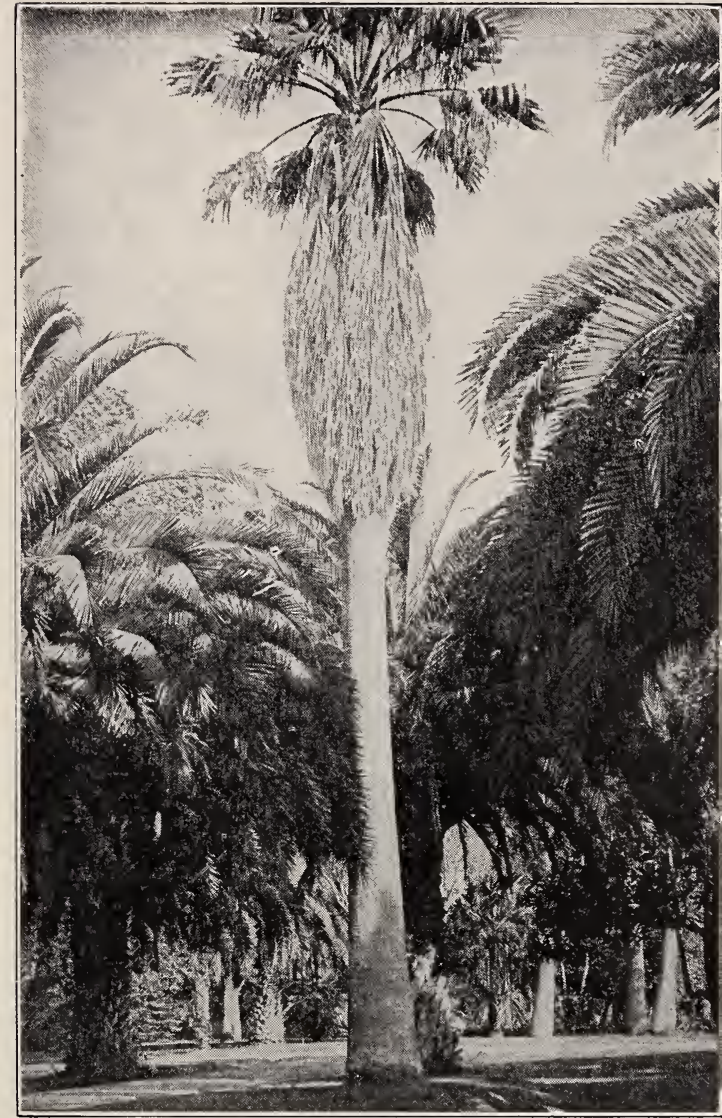

California Fan Palm and Phoenix Carariensis

AGAVE, AMERICAN. 6-inch pots, 75c each.

AGAVE, AMERICAN VARIEGATED. 5-Inch pots, $75 \mathrm{c}$ each. Larger, $\$ 1.00$ and $\$ 1.50$ each.

BAMBOo. Of medium sized growth; foliage bright green. $\$ 2.50$ per clump.

BRAHEA EDULIS. It has very large fan-shaped leaves of bright green color; is never affected by heat or cold.

CALIFORNIA FAN PALM. See Washingtonia.
Chamaeropsis excelsa (Japanese Fan Palm). One of the hardiest of the Fan Palms. 75c, $\$ 3.00$ and $\$ 3.50$ each.

CHAMAEROPS HUMILIS, Dwarf Fan Palm. Dwarf, hardy Palm. Leaves very small with spiny stalks, segments rigid and double-pointed. A very useful Palm for a small lawn. Fine for tub culture. Handsome and requires but little space. 7-inch pots, $\$ 2.50$ each.

DRACAENA INDIVISA. A fine plant for outdoor planting in California, and much in use for lawns, avenues and parks. Balled, $11 / 2$ to 2 feet, $75 \mathrm{c}$ each; $21 / 2$ feet, $\$ 1.50$ each; 3 feet, $\$ 2.00$ each.

*Kentia Belmoreana. This fine palm is a valuable addition to our collection. Its leaves are pinnate, dark green and so beautifully crisp as to gain for it the name of "Curly Palm." 5-inch pots, $\$ 2.50$.

*Kentia fosteriana. One of the finest of the Kentias, with graceful, light green foliage. 5-inch pots, $\$ 2.50$.

PAMPAS GRASS. $75 \mathrm{c}$ and $\$ 1.00$ each.

PHOENIX CANARIENSIS (The Canary Island Date). Balled, $1 \frac{1}{2}$ feet, $\$ 2.00$ each; $2 \frac{1}{2}$ feet, $\$ 3.00$ each.

PHOENIX REClinata. A fine variety; good for house decoration. 6-inch pots, $\$ 1.00$ each.

WASHINGTONIA ROBUSTA. One of the most beautiful of our native palms; leaves fan-shaped. Balled, $21 / 2$ feet, $\$ 1.50$ each; $31 / 2$ feet, $\$ 2.00$.

Fukien, China.

I wish to send thanks for the careful packing which brought the trees here in fine condition. There were delays at Shanghai and Foochow, so that the box did not arrive here until nearly two months af ter the date shipped from Oakland. However, when the trees were unpacked everything was found to be in good condition.

P. H. $\mathrm{P}$.

I am pleased to state that the roses reached me in perfect condition. A. P. T.

Chekiang, China.

The fruit trees and grape vines were safely received; the trees were very good and plump.

M. L. C.

San Angel, Mexico.

I am very well satisfied with your roses which arrived in fine condition. Your plants are the best $I$ have ever received from the United States. I congratulate you on your packing.

A. M. C. Moji, Japan.

I received this morning the parcel of roses. They were 50 days in transit, and out of the 54 sent, only one was dead.

Our method of packing for foreign shipments, as is evidenced by the above letters, is of the very best, and we solicit orders from Mexico, Central America, China and Japan.

\section{DECIDUOUS ORNAMENTAL AND AVENUE TREES}

ALMOND, Double Pink Flowering. 3 to 5 feet, $\$ 1.00$ each. APRICOT, Double Flowering. 3 to 5 feet, $\$ 1.00$ each.

APPLE FLOWERING. BETCHELLS, DOUBLE LIGHT PINK. 3 feet, $\$ 1.50$ each.

APPLE FLOWERING. PARKMANS. Single deep flowers along the stems. 3 to 4 feet, $\$ 1.50$ each.

CUT LEAVED WEEPING BIRCH. A very graceful tree, with silvery bark, as it attains age. 5 to 6 feet, $\$ 2.00$ each.

HAWTHORNE. Paul's Double Scarlet. 5 to 6 feet, $\$ 1.50$ each.

LABURNUM. A beautiful medium sized growing tree, producing long, drooping racemes of fragrant yellow flowers. 4 to 6 feet, $\$ 1.00$ each.

MAPLE, SILVER, OR SOFT. A rapid-growing tree; foliage bright green above, silvery beneath. 7 to 8 feet, $\$ 1.50$ each.
PLUM, PURPLe-LeAVED. 5 to 6 feet, \$1.25 each.

POPLAR, LOMBARDY. A very rapid, erect growing tree, witn a tall, spiry form and particularly striking and picturesque. 6 to 8 feet, $\$ 1.25$ each.

PEACH, DOUBLE FLOWERING. Red, White and "Early" Red, Separate colors. 4 feet, $\$ 1.25$ each.

SYCAMORE, EUROPEAN. This variety is much in demand for sidewalk planting. 6 to 8 feet, $\$ 1.75$ each.

*TAMARIX AFRICANA. 3 to 4 feet, 80c each.

TAMARIX AESTEVALIS. 3 to 4 feet, $\$ 1.00$ each.

WALNUT, CALIFORNIA BLACK. One of the best shade trees for California; of rapid growth. 4 to 5 feet, $75 \mathrm{c}$ each.

WILLOW, FRENCH PUSSY. 2 to 3 feet. 75c each.

WILLOW, WEEPING. A rapid growing tree with drooping branches, leaves long and narrow. 6 to 8 feet, $\$ 1.25$ each. 


\section{CLIMBING AND TRAILING PLANTS}

AMPELOPSIS EVERGREEN. This variety clings like the Boston Ivy, but is an evergreen. $60 \mathrm{c}$ each.

AMPELOPSIS QUINQUefoliA (Virginia Creeper). The leaves are palmate, handsome and luxuriant, assuming in autumn a gorgeous bronzy hue. 60c each; $\$ 5.00$ per 10.

AMPELOPSIS VEITCHII (Boston or Japan Ivy). This varlety clings closely without any assistance to a stone wall or brick flue, or a wooden surface. $50 \mathrm{c}$ and $75 \mathrm{c}$.

AUSTRALIAN PEA VINE. This lovely fast-growing climber we can recommend to those desiring a rapid grower. The flowers are pea-shaped, pink and produced in great luxuriance. $35 \mathrm{c}$ each.

BOSTON IVY. See Ampelopsis Veitchii.

BOUGAINVILLEA BRAZILIENSIS. Have peculiarly shaped flowers, somewhat resembling the leaves in shape, the color being of a rosy lake, and produced along the branches in wonderful profusion. $\$ 1.00$ and $\$ 1.50$ each.

BIGNONIA CHERERE. Large, showy trumpet-shaped flowers, deep crushed strawberry red; $\$ 1.00$ each.

BIGNONIA GRANDIFLORA (Trumpet Vine). Rapid-growing climber, bearing large orange-yellow trumpet-shaped flowers in great profusion. 75c each.

CHORIZEMA ILLICIFOLIA. A very attractive "climbing" shrub; produces pea-shaped flowers, color orange-red, beautiful shade, in great profusion; leaves "holly" like. 75c and $\$ 1.00$ each.

CLEMATIS MONTANA. Medium sized white flowers; very floriferous. 5-inch pots, $80 \mathrm{c}$ each.

EUONYMUS RADICANS, VARIEGATA. Extremely handsome plant for parkings. 4-inch pots, 50c each.

FICUS REPENS. A very pretty, useful climber; clings to stone, brick or wood; like the Boston ivy. Evergreen. 50c, 75c and $\$ 1.00$ each.

FICUS NITIDA. Leaves much smaller than preceding. $80 \mathrm{c}$ each.

HOP ROOTS. 10c each; 50c per 10.

HONEYSUCKLE, CHINESE. Rosy white; very sweetly scented. $35 \mathrm{c}$ and $50 \mathrm{c}$ each.

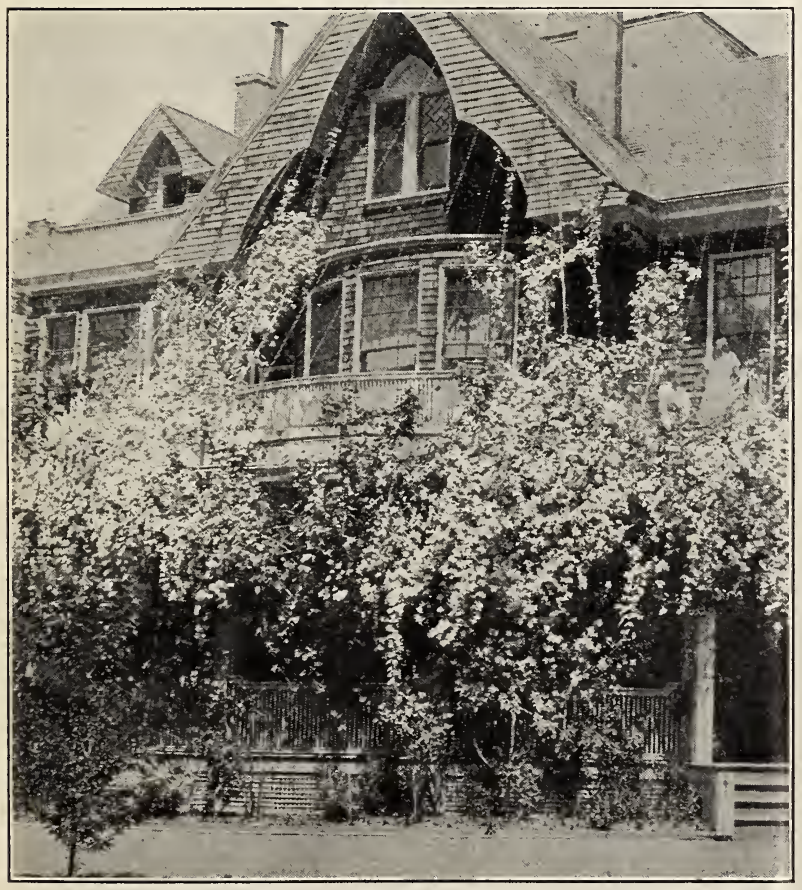

Clematis Montana
HONEYSUCKLE, HALLEANA. A strong, vigorous, almost evergreen sort, with pure white flowers, changing to yellow; very pragrant; a long and continuous bloomer. $35 \mathrm{c}$ and $50 \mathrm{c}$ each.

HONEYSUCKLE. Gold netted. $35 \mathrm{c}$ and $50 \mathrm{c}$ each.

HOYA CARNOSA. "Wax Plant" flowers; come in terminal clusters, in great profusion; color creamy white; of very rapid growth. 75c each.

IVY, ENGLISH, LARGE-LEAVED. Leaves thick, shining, leathery. In flats of $50, \$ 3.00$; from pots, $25 \mathrm{c}$ and $35 \mathrm{c}$ each.

JASMINE NUDIFLORUM. Fragrant yellow flowers in very early spring in great nrofusion. 75c each.

JASMINE OFFICIONALIS. Single white flowers. 90c each.

JASMINE PRIMULINUM. Golden yellow; the blossoms are fully two inches in diameter, and in early spring-time the plant is one mass of blooms. $40 \mathrm{c}$ and $75 \mathrm{c}$ each.

LOTUS PELIORHYNCUS. A dainty plant of creeping habit; foliage glaucous, lace-like; flowers scarlet. $35 \mathrm{c}$ each.

MUEHLENBRECKIA COMPLEXA (New Zealand Mattress Vine). This pretty, strong-growing climber and trailer is very desirable for covering old stumps of trees, rockwork, etc. $35 \mathrm{c}$ and $50 \mathrm{c}$ each.

PEA VINE, EVERLASTING. This variety dies down in winter, but makes a wonderful growth during summer.

PASSION VINE. Scarlet. Of rapid growth, and very attractive when covered with the large handsome flowers. 4-inch pots, 40c each.

PLUMBago CAPENSIS. Flowers light sky-blue, verbenashaped, 60c each; Plumbago White, $40 \mathrm{c}$ each.

SOLLYA (Australian Bluehill). $80 \mathrm{c}$ each.

\section{THE WISTERIA}

Very hardy, growing in cold countries to perfection. offer the following varieties. Strong plants. \$1.50 each.

CHINENSIS. Clusters about a foot long; flowers single, pale blue.

MULTIJUGA ALBA. Bears long racemes of pure white flowers.

VINCA, VARIEGATED (Perewinkle). Flowers blue, fine for covering banks. 4-inch pots, $35 \mathrm{c}$ each.

\section{HARDY FERNS}

The following varieties are all hardy, especially around the Bay District; for shady and partially shady places ferns are very effective and add wonderfully to the beauty of the garden. We offer the following varieties.

ADIANTUM PEDATUM. "Five-Fingered Fern". This native variety is well known; very dainty and graceful. $50 \mathrm{c}$ each.

ASPLENIUM FELIX-FOEMINA. "Lace Fern". Very lacy in appearance; color of fronds very pleasing green; grows to a height of $1 \frac{1}{2}$ feet. $60 \mathrm{c}$ each.

ASPLENIUM FELIX-FOEMINA. "Slender Lace Fern." Similar to preceding, but of drooping habit. $40 \mathrm{c}$ each.

PTERIS TREMULA. Attains a height of two feet; fronds green on upper side and silvery green on under side. $75 \mathrm{c}$ each.

POLYSTICHUM SETOSUM. Fronds very glossy dark green, a handsome variety. 75c each.

POLYSTICHUM CAPENSE. "Leather Leaved Fern." Fronds very shiny; of erect, rapid growth. $75 \mathrm{c}$ each.

POLYSTICHUM TSUSSINENSE. Native of Japan, of dwarf habit; fronds very dark green. 60c each.

POLYSTICHUM MUNITUM. A native Sword fern, growing to a height of $1 \frac{1 / 2}{2}$ feet high; one of the best ferns. 75c each.

SUNBREAK FERN. Elegant large growing fern; attains a height of 4 feet; fronds of soft downy appearance. $75 \mathrm{c}$ each.

WOODWARDIA FERN. This native variety grows rapidly and produces long elegant fronds. $35 \mathrm{c}, 50 \mathrm{c}$ and $75 \mathrm{c}$ each, according to size. 


\section{CARNATIONS}

3-inch pot plants, $20 \mathrm{c}$ each; $\$ 2.00 \mathrm{doz}$. except where noted otherwise. Ready February.

BELLE WASHBURN. Deep red.

BENORA. White streaked and splashed pink.

DONALD. Crimson; large and fragrant.

LADDIE. WVarm rose-salmon; silvery in appearance; flne. 30c each: $\$ 3.00$ per 12.

MAINE SUNSHINE. Very fine, new yellow sort. 30c each; $\$ 3.00$ per 12.

MATCHLESS. Pure white, of excellent form; long stemmed and free flowering; petals fringed.

MORNING GLOW. Silvery pink.

MRS. C. W. WARD. Deep pink.

\section{VIOLETS}

MARIE LOUISE. The well-known double light purple variety. $75 \mathrm{c}$ per dozen.

PRINCESS OF WALES. Very large flowers, violet blue; single, sweetly scented; stems long; very free in bloom. $60 \mathrm{c}$ per dozen.

\section{FUCHSIAS}

4-inch pots, 35c each; $\$ 3.00$ per dozen.

ABBE FARGES. Extremely double. Sepals very much reflexed. Corolla reddish violet. Giant in size.

"BABY" FUCHSIA. Very small, graceful flowers.

BLACK PRINCE. Purple; double.

EMILE LAURENT. A very free blooming variety. Sepals clear rose; corolla rose and white; double.

GEROLSTEIN. Sepals white; corolla bluish pink; single; tall grower.

PHENOMENAL. Large double purple.

PROCUMBENS. Small foliage; of creeping habit.

RICORTIANA. Very small flowers; a miniature variety.

STORM KING. Double white.

TORPILLEUR. Sepals intense red; giant double corolla. Color white, shaded rose. Extra fine; double.

\section{Large Flowered Chrysanthemums}

Ready about May 1 st. $20 \mathrm{c}$ each, $\$ 2.00$ dozen.

CHIEFTAIN. A beautiful, incurving pink of perfect shape. DR. ENGUEHARD. Grand variety; color, pink.

GLENVIEW. Dark bronze and clear red.

HARVARD. Reflex from dark crimson; excellent.

ODESSA. Splendid incurved form, bright yellow

PACIFIC SUPREME. Brilliant pink. Midseason.

ROSE PERFECTION. Fine shade of rose. Nidseason.

RICHMOND. Bright golden yellow, of perfect form.

SMITH'S SUbLIME. A fine lavender pink. Early.

SMITH'S SENSATION. A grand early white; very free.

TEKONSHA. A splendid large bronze. Midseason.

TINTS OF GOLD. A valuable early bright bronze.

WHITE CHIEFTAIN. A grand white sport from Chieftain.

WILLIAM TURNER. Purest possible white.

YELLOW TURNER. Pale yellow.
THREE NEW ANEMONE FLOWERING

\section{CHRYSANTHEMUMS}

25c each; \$2.50 per 12

FLORERA-Color, light yellow with an exceptionally large

cushion which nearly extends to the ends of the ray

florets. Very distinct and striking. A grand new sort.

PRIMROSE-Clear light yellow, dwarf; fine pot plant.

PURITAN-A fine pure white; excellent for pot culture.

\section{POMPONS-VARIETIES}

$15 \mathrm{c}$ each; \$1.50 per 12.

BALDWIN'S SCARLET. Golden scarlet; splendid form.

GOLDEN CLIMAX. Standard deep yellow.

ILLONA. Rosy lavender; strong grower.

LEILAH. A rose pink, of exceptional merit.

OURAY. Dark mahogany brown, best in its color.

WOLVERINE. A bright yellow; very hardy.

\section{BUTTON TYPE POMPONS}

15c each; \$1.50 per 12.

BABY DOLL. Light yellow tinted bronze.

FRANK WILCOX, JR. An orange bronze; excellent sort.

HILDA CANNING. A very attractive rosy bronze.

WHITE MIDGET. A fine pure white.

\section{SINGLE CHRYSANTHEMUMS}

15c each; \$1.50 per 12.

BRONZE BUCKINGHAM. IVonderful coppery rose color.

DAZZLER. The brightest possible shade of crimson.

GARZA. The purest white, yellow center.

OLD GOLD. Orange yellow and bronze.

RICHARD DELAFAELD. Terracotta scarjet shadings.

W. BUCKINGHAM. A grand, vigorous pink.

\section{GERANIUMS}

Price of plants from 3-inch pots, $15 \mathrm{c}$ each; $\$ 1.50$ per dozen. BELLE POITEVINE. Large handsome trisses of salmon-colored flowers.

JEAN VIAUD. Soft, pure pink, with two white blotches; dwartstocky grower, rigid stems, large trusses, perfect florets; semi-double.

GENERAL GRANT. A splendid double salmon red; trusses very large and showy.

GERTRUDE PEARSON. Rosy pink, white eye; one of the best; single.

MRS. GLADSTONE. Very pale pink; single.

NEWSOM. A beautiful single scarlet, shading to red; immense trusses and very free flowering.

SINGLE WHITE.

S. A. NUTT. The very best of the double dark crimson scarlets.

THE CLYDE. An immense single scarlet; trusses very fine. Extra strong grower.

THE SWAN. A grand double white variety, constantly in bloom.

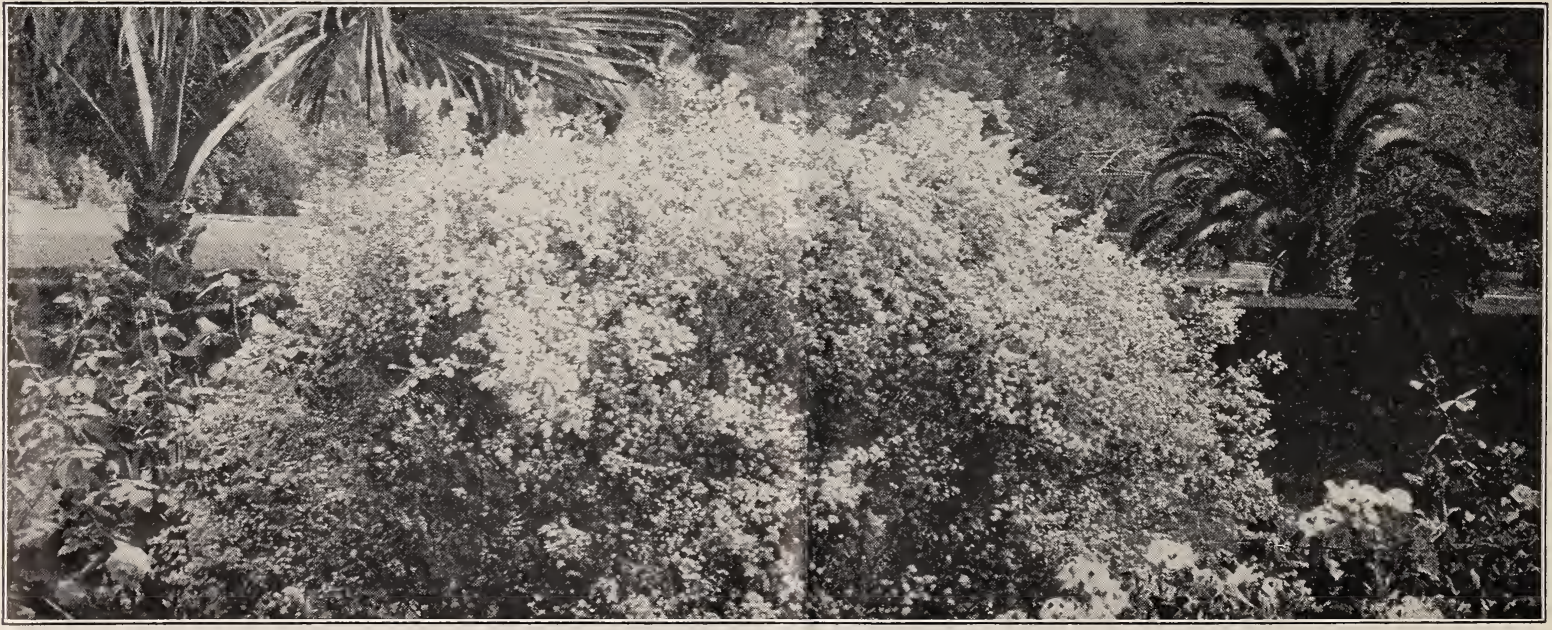

Diosma in Foreground. 


\section{HERBACEOUS, BEDDING AND MISCELLANEOUS PLANTS}

ACHILLEA ROSEA (Milfoil or Yarrow). Suitable for dry, sunny places; blooms freely all summer; flowers pink; 25c each; \$2.50 per 12.

ALSTROMERIA. (Peruvian Golden Lily.) This is the beautiful golden-spotted Peruvian Lily you see often in the florists' windows. Vèry free in bloom. 25c each; \$2.50 per 12.

ANChUSA ITALica. Flowers intense blue. Very fine perennial. 60c per dozen.

ANTHERICUM VARIEGATUM. ("Spider Plant.") Foliage prettily tipped yellowish white; a nice basket or window plant. 35c each.

ARABIS ALPINA (Rock Rose). Pure white flowers; $20 \mathrm{c}$ each; $\$ 2.00$ per 12.

ARALIA SIEBOLDII. A remarkably pretty shrub; leaves are somewhat like the fig leaf; it makes a nice house plant and when planted out of doors, makes a handsome specimen. 60c each.

ASPARAgUS PLUmosus. A very nice house plant, or it can be planted in protected place in the garden; it climbs very nicely. $75 \mathrm{c}$ and $\$ 1.00$ each.

ASPARAGUS SPRENGERII. Fine house plant, and much used for hanging baskets or window boxes. 75c, $\$ 1.00$ and $\$ 1.50$ each.

ASTE.R, MICHAELMAS DAISY. Violet-blue flower's; 20c each; $\$ 2.00$ per 12

ASTER, SEMPLE'S NEW BRANCHING. Grimson, lavender, pink and white. Ready about April 15th. 50c per 12.

AQUILEGIA. Columbine. These well-known perennials should be in every collection; the great profusion of bloom and their exquisite blossoms are certainly very beautiful. We have a strain of the very best colors to offer. 60c per dozen.

BEGONIA VERNON. Dark pink, foliage bronzy in sun. 60c per 12; $\$ 6.00$ per 100

BOSTON FERNS. $\$ 1.50$ and $\$ 2.50$ each.

BUDDLEA VARIABALIS. "Butterfly Plant." Flowers lilac, borne profusely in long spikes; very fragrant; continuous bloomer. 5-inch pots, 60c each.

CAMPANULA. Medium. Very pretty and showy; blue and white. 15c each; \$1.25 per 12.

CAMPANUlA. (Cup and Saucer.) Pink white and blue. 10c each; $\$ 1.00$ per 12.

CAMfANULA PERSICIFolia (Peach Bells). Tall growing flowel's, blue. 25c each; \$2.50 per 12.

CHELONE BARBATUS. Coral-red; spike shaped; grows about 2 feet high. 25c each; $\$ 2.50$ per 12.

CINERARIA. As a winter blooming plant for house culture, or for use for bedding under the shade of large trees, these are invaluable. We offer a fine strain. $\$ 1.50$ per 12.

CALCEOLARIA YELLOW. A splendid bedding or border plant; produces its showy yellow flowers for a very long period. $50 \mathrm{c}$ each; $\$ 1.50$ per dozen.

COREOPSIS LANCEOLATA. The flowers, which are yellow, are of graceful form, are invaluable for cutting for decorative purposes. 75c per 12; stronger, \$1.00 per 12.

COCOLOBA PLATYPHILA. An odd-looking plant, with jointed stems; bright green foliage; of quick growth. 5-Inch pots, $75 \mathrm{c}$ each.

cosmos. Crimson pink, white and yellow. Ready about April 15th. 50c per dozen.

DAISIES. Double, all colors. 50c per 12.

DELFHINUM HYBRIDUM. All shades of dark and light blue. 25c each; \$2.50 per 12.

DIANTHUS CAESIUS (Chedar Pink). Very compact in growth; flowers rose colored. 25c each; \$2.50 per 12.

DIGITALIS. Fox Glove. Tall growing plants, throwing up very long spikes of lovely bell-shaped flowers, in great profusion; all colors. 10c each; \$1.00 per 12.

ECHEVERIA (Hen and Chickens). 75c per 12.

ERYNGIUM (Sea Holly). Graceful foliage with thistlelike heads of steel blue. 25c each; $\$ 2.50$ per 12.

FORGET-ME-NOT. (Myosotis.) Small blue star-like flowers borne in clusters on long stems. 50c per 12.

GAILLARDIA GRANDIFLORA. Flowers bronze scarlet, bordered with golden yellow, three inches in diameter, produced on long stems. 60c per 12 .
GAZANIA SPLENDENS. Produces masses of orange-yellow flowers in spring; beautiful for banks and borders. 500 per 12; $\$ 3.00$ per 100.

GEUM. Lady Strathden. Yellow flowers. 10c each; 75c per 12. GEUM. MRS. BRADSHAW. Large scarlet flowers; a very showy perennial. 75c per 12.

GOLDEN FEATHER. (Feverfeu). This plant is much used for making borders and beds; foliage yellow. 35c per 12; $\$ 2.50$ per 100.

HELIANTHUS ANGUSTIFOLIA. A lovely perennial sunflower, single yellow. 20c each; $\$ 2.00$ per 12.

HELIOTROPE QUEEN. Very dark. 35c each.

HELIOTROPE SAPPHIRE. Purple, white center. 35c each.

HELIXINE. A dainty creeping plant; good for rockeries. \$3.00 per flat.

HOLLYHOCK. Double fine selection. 60c per 12.

HEUChERA SANGUiNeA. Coral Gem. Produces dainty, beautiful pink flowers, on a stem of about $1 \frac{1 / 2}{2}$ feet high; always in bloom; fine for borders or massing in beds. $75 \mathrm{c}$ per 12.

INDIAN CURRANT. Very showy; in the fall it produces berries of a darkish red color all along the branches. 50c each.

IRIS FOETIDISSIMA. This variety is beautiful when it produces its lovely red seeds, that come in a pod, which bursts open at a certain period; after cutting they keep for a long time, and are very ornamental. Strong clumps. 50c each; \$4.00 per 10.

ISOLEPIS GRACILIS. A pretty "grass like" plant, with drooping foliage; very nice for hanging baskets, or edges of pools. $50 \mathrm{c}$ each.

LANTANA. Extremely pretty plants, producing their odd colored brownish-yellow flowers in great profusion for a long period. 4-inch pots, 40c each.

LANTANA. Lavender colored flowers; a very pretty variety of creeping habit. 4-inch pots, $40 \mathrm{c}$ each.

LAVENDAR, ENGLISH. 4-inch pots, 50c each.

LEONITIS. "Lion's Tail." Flowers ruddy orange, borne on whorls around the branches; very showy. 5-inch pots, $50 \mathrm{c}$.

LIPPIA REPENS. Used to make lawns; requires very little water. \$2.00 per 100.

LOBELIA. Dwarf blue. 35c per 12; \$2.50 per 100.

MARGUERITE BLUE. (Agathea coelestis.) Sky-blue flowers, yellow center. 15c each.

MARGUERITE, WHITE. 15c and 25c each.

MARGUERITE, YELLOW. $15 \mathrm{c}$ and $25 \mathrm{c}$ each.

MARIGOLD. 35c DER 12.

MESEMBRYANTHEMUM. Lavender flowers. 50c per 12; $\$ 2.50$ per 100.

MESEMBRYANTHEMUM PINK. These are much used for bedding purposes and planting on banks and hillsides. $60 \mathrm{c}$ per 12; $\$ 3.00$ per 100.

MINT PLANTS. Strong roots. 35c each.

Moss, SCOTCH. (Inopsidum.) Makes a pretty green carpet, frequently used between the stepping stones ( $\$ 2.50$ per fiat), which can be divided into many plants.

PANSIES. 50c per 12.

PENTSTEMON. Very ornamental plants, producing long spikes of showy colors in great abundance. Assorted colors, $10 \mathrm{c}$ each; \$1.00 per 12.

PENSTEMON ("South Gate Gem"). Beautiful scarlet flowers. $15 \mathrm{c}$ each; $\$ 1.25$ per 12.

PETUNIAS, GIANTS OF CALIFORNIA. Mixed colors. From flats, 75c per 12. Ready in March.

PHYSTOSTOGIA VIRGINicA (False Dragon Head). Delicate lilac-pink flowers. 25c each; \$2.50 per 12.

PLUMBAGO LARPENTAE. Of creeping habit; produces dark blue flowers in great profusion. $35 \mathrm{c}$ each.

POLEMANiANA COERULEM (Jacob's Ladder). Foliage "fer"nlike" with spikes of blue flowers. 25c each; \$2.50 per 12.

POPFY, ICELAND. Produces very graceful flowers, resembling crumpled tissue paper; mixed colors. 60c per 12.

POPPY ORIENTAL. \$1.00 per dozen.

PRIMROSE, BABY. (P. Malacoides.) Produces flowers in great profusion, borne on long stems; very showy. 60c per 12. 


\section{PERENNIAL AND BEDDING PLANTS - Continued}

PRIMROSE, COMMON. Mixed colors. 60c per 12.

PRIMULA AURICULA. Flowers come in maroon, garnet, lavender and yellow. Mixed colors. 15c each; \$1.50 per 12.

PYRETHRUM, hYBRIDS. Flowers "Cosmos like" in appearance, borne on stout stems, and in great profusion; mixed colors. 60c per 12.

RUDBECKIA (Golden Glow). Double golden yellow flowers. 20c each; \$2.00 per 12.

RUEBECKIA LACINEATA. Golden-yellow flowers, double, borne very freely; quite showy. 20c each; \$1.75 per 12.

SALVIA LEUCANTHA. Violet-purple flowers, tipped white, and borne in whorls which are 6 to 10 inches long; very free in bloom. Large plants, 60c each.

SALVIA SPLENDENS. Scarlet flowers; continuous bloomers. Ready March. 10c each; 60c per 12.

SALVIA TURKESTANICA. Decorative foliage, with whorls of white flowers surrounded pale pink. 25c each; $\$ 2.50$ per 12.

SANTOLINA. A beautiful horder plant; foliage silvery gray; stands trimming well. $\$ 2.50$ per 100 .

SCABIOSA CAUCASICA. (Blue Bonnet.) Large pale blue flowers, borne on long stems and for a long period; flne for cutting. 15c each; \$1.50 per 12.

SEA PINK (Armeria). Very dwarf, requiring no trimming. Flowers rose-pink. 50c per 12; $\$ 2.50$ per 100.

SHASTA DAISY (Alaska). The flowers are very large, borne on long stems and very free in bloom. Single white, with yellow center. 60c per 12.

SIDALCEA ROSEA. Erect-growing plants producing rose pink flowers very freely. 25c each; \$2.50 per 12.

SNAPDRAGON. Fine varieties, in separate colors. 50c per 12. SOLIDAGO, (Golden Rod). Flowers yellow. 20c each; \$2.00 per 12.

STRAWBERRY. "Evergreen or Wild." Fine for covering embankments. 50c per 12; $\$ 2.50$ per 100.

sTocks. In fine assortment. 35c per 12.
SWEET WILLIAM. MiXed colors. 60c per 12.

TRACHELIUM COERULEUM. "Cloud-like" heads of pale mauve and white, resembling Gysophylla somewhat. 25c each; $\$ 2.50$ per 12.

TRITOMA UVARIA. (Red Hot Poker Plant.) Foliage "grassylike"; flowers deep orange, borne for a long period on stout stems; very showy. 35c and 50c each.

VALERIAN (Centranthus ruber.) Showy hardy bedding plants producing large corymbs of red or white flowers. 60c per 12.

VERBENA, MAMMOTH. All colors. Ready March. 10c each; 75c per 12.

VERONICA (Speedwell) SPICATA. Of creeping habit; good for rockeries; bright blue flowers. 25c each; \$2.50 per 12.

WALLFLOWER. $50 \mathrm{c}$ per 12.

WOODWARDIA FERN. $60 \mathrm{c}$ each.

\section{CANNAS}

25c each; \$2.50 per dozen (except where noted).

AUSTRIA. Deep yellow; flowers very large.

FIREBIRD. Intense scarlet. 30c each; \$3.00 per 12.

KING HUMBERT. Deep scarlet, bronze foliage. 30c each; $\$ 3.00$ per 12.

INDIANA. Deep orange-red, flecked old gold; green foliage.

SHENODOAH. Deep rose-pink; bronze foliage.

WYOMING. Beautiful orange; bronze foliage.

\section{IVY LEAF GERANIUMS}

Are indispensible for covering banks, fences, etc. They are almost continuously in bloom, and require very little water. CHARLES TURNER. The color is a bright pink, quite doubie. Very useful ror window boxes and rockeries.

CARLOS UHDEN. A magniflcent new variety, quite double; color rosy scarlet; grand for window boxes and Nanks, always in bloom.

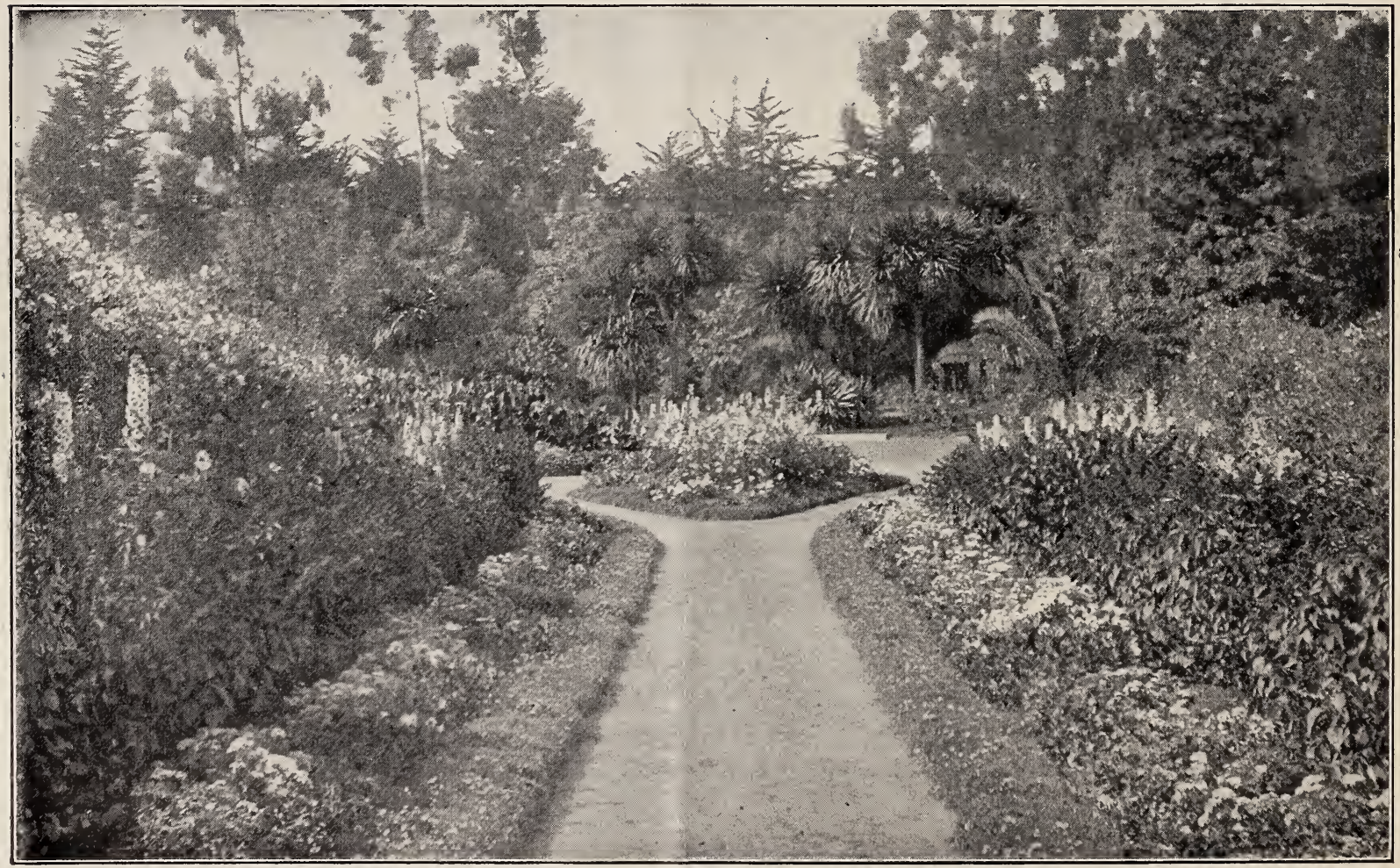

The Perennial Plant Garden. 


\section{FRUIT TREES AND SMALL FRUITS}

The California Cultivator (a paper devoted to horticulture in this state) submitted to us the following questions and asked us to give them an answer thereto. As they bear very greatly on fruit tree planting in California, and we receive such questions daily from intending planters, we thought we would help planters by giving the questions and our reply. We know it will be of great assistance to the novice in fruit tree planting.

1. How many months are included in the best planting period, i. e., how early may fruit trees be taken from nursery in fall and how late may they be planted?

1. Late December, January, February, and early March.

2. Where is it best to plant them, i. e., can you give a general idea as to planting figs, apples, pears, cherries, walnuts, peaches, and such other fruits? Of course, if you covered all the fruits, this would take too much time, but whatever information you can give is greatly needed by tree planters. Orchard after orchard has been set out, only to prove a failure because owners did not understand this question.

2. Figs should be set out in the warmer sections, principally the San Joaquin and Sacramento Valleys, and the other fruits mentioned can be planted from Mendocine to San Diego. The intending planter, however, must use his own judgment about the best locations for each of these fruits.

3. What age and size of tree is best?

3. The best tree to plant out is what nurserymen call "oneyear-old" trees; the root is a year older, so this practically makes the trees two years old, but nurserymen style them "one-yearold;" either three to four feet high or four to six feet high.

4. How large and how deep should holes be?

4. In sedimentary land, the hole does not require to be so very large, $1 \frac{1}{2}$ feet square will cover it. In heavier soil two feet will be necessary.

5. Is it best to plant any deeper in well-prepared soil than tree was set in nursery?

5. Plant a little deeper than what they were in the nurserynot more than one inch.

6. Would you recommend close pruning of roots before planting or simply trimming mutilated ends? If you favor close trim. ming of roots, would you go to the extremes recommended in the Stringfellow method?

\section{APPLES}

Price, 4 to 5 feet, 65c each; \$6.00 per 10.

ALEXANDER. Greenish white, streaked red; a fine early variety. DELIClous. A very fine eating apple, tender and of fine flavor; ripens late.

ESOPUS SPITZENBERG. Large, light red, rich. Sprightly; vinous flavor. November to January.

GRAVENSTEIN. A large striped, beautiful, roundish apple; of excellent quality, juicy, high flavored. Ripe in August.

JONATHAN. Light yellow, with red stripes; tender and juicy. Ripens October and November.

RED ASTRACHAN. Large; skin deep red, flesh white; juicy and crisp; ripens June and July.

WHITE WINTER PEARMIN. Large, roundish, oblong and pale yellow; dotted with brown. Ripe December to February.

WINTER BANANA. A very fine late variety, of excellent quality.

YELLOW NEWTON PIPPIN. Large; flesh yellow, firm, crisp, juicy, of exceedingly rich flavor. Ripe January to March.

YELLOW BELLEFLOWER. Very large, oblong, irregular and tapering toward the eye. Ripens November.

\section{CRAB APPLES \\ Hyslop and Yellow Siberian.}

\section{CHERRIES}

Price, 4 to 6 feet, $70 \mathrm{c}$ each; $\$ 6.50$ per 10.

BING. Fruit large, dark brown or black; very fine; late. A good shipping variety.

BLACK TARTARIAN. Very large, bright black. The favorite. ENGLISH MORRILLO. Large dark red; a sour sort.
6. We recommend medium cutting back of the roots. We would not go to the extreme as Mr. Stringfellow does, although we practice it a great deal in our nurseries when we are lining out young stock, and have good success with it.

7. Would you top trees, i. e., take off greater portion of top grown in nursery, and if so, before or after setting? Would you do it by exact measurement the orchard over, or according to vigor of trees?

7. Trees should be pruned after planting, not before. They

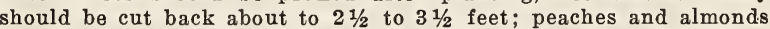
should have some of the laterals left; prune these to two or three inches from the stem; the main stem has often blind eyes; apricots, prunes, pears, apples and plums can be trimmed to single stem.

8. If irrigation water is available, would you settle dirt about the trees with water or by tamping?

8. In the drier sections it is a good idea to use irrigation to settle the soil around the roots after planting, but in the northern parts and in the Santa Clara Valley, where the rainfall is good during the months of January and February, this is not necessary. Work the soil carefully around the roots; in light soil heavier tamping can be done than in heavy, wet land.

9. Would you advise use of fertilizer or manure, either in hole or on surface, at time of planting?

9. In planting large orchards no fertilizing is done.

10. Is any advantage gained by protecting trunks of newly planted trees from rays of sun? If so, what method is best?

10. It is very necessary to protect the trunks of young trees during the first summer months, either by tulle tree protectors, shakes set on the sunny side, or by wrapping newspaper and tyıng with a cord. This keeps the tree from getting sunburnt and is certainly of great benefit to the young tree.

NAPOLEON BIGARREAU (Royal Ann). Very large; amber in color. The favorite white cherry.

\section{PEARS}

Price, 4 to 5 feet, 65c each; $\$ 6.00$ per 10.

BARTLETT. Bears heavily; good for shipping and canning. Ripe in August.

BEURRE HARDY. Large, russety, juicy and melting; very fine. Ripens in August.

DOYENNE DE COMICE. Fruit large, of roundish shape, tapering towards stem; very sweet and delicious. Ripens October.

WINTER NELLIS. Medium size, roundish, yellowish green, dotted with russet. November to January.

\section{PLUIVIS}

\section{4 to 6 feet, $65 \mathrm{c}$ each; $\$ 6.00$ per 10 .}

BEAUTY. Crimson, sprinkled whitish dots; flesh, amber in color; very sweet, early.

BURBANK. Yellowish ground, red cheek; flrm.

DAMSON. A fine blue plum, good for preserves.

FORMOSA. Very large, healt-shaped; skin cherry-red; flesh pale yellow, sweet and delicious.

GREEN GAGE. Round, greenish yellow, with brown dots; very juicy and sweet. August.

JEFFERSON. Skin golden yellow; red cheek; of lucious flavor.

SANTA ROSA. Very large; skin deep purplish crimson with pale blue bloom; flesh purple-shaped rosy scarlet.

SATSUMA. Japanese "Blood Plum." Flesh red.

WICKsoN. Fruit heart shaped; skin deep cherry red; meat amber colored; very juicy; pit small. 


\section{FRUIT TREES AND SMALL FRUITS-Continued}

\section{PEACHES}

Price, 4 to 5 feet, $65 \mathrm{c}$ each; $\$ 6.00$ per 10.

*ALEXANDER. Flesh firm and juicy, sweet. Ripens early in June.

*BRIGGS RED MAY. Medium to large; skin greenish white; flesh melting and juicy. Ripens middle of June.

EARLY CRAWFORD. Very large; bright yellow, with a beautifully mottled red cheek; flesh yellow, juicy, sweet. Ripens last of July. Freestone.

ELBERTA. Very large; skin yellow-red cheek; flesh yellow, juicy, rich, sweet and of fine flavor; freestone. Ripens about middle of August.

J. H. HALE. A valuable new variety; yellow freestone; flesh tender, excellent qualitv; very large and heavy producer. Ripens middle of August.

LATE CRAWFORD. Large, freestone; flesh deep yellow, excellent flavor. Ripens early September.

MAYFLOWER. "The earliest of all Peaches;" skin red; flesh white, excellent flavor; very heavy bearer; freestone.

MUIR. Has a delicious rich, buttery, sweet flavor. Freestone. Ripens end of August.

PHILLIPS CLING. The best late clingstone.

*STRAWBERRY. Medium size; flesh white; mid-season.

TUSCAN CLING. A very fine early clingstone; a good shipping and canning sort.

Those varieties "starred" are good only for eating fresh.

\section{PRUNES}

4 to 6 feet, $65 \mathrm{c}$ each; $\$ 6.00$ per 10.

FRENCH (Petite d'Agen). This is the prune now grown so extensively and successively in California for drying purposes; medium-sized; egg-shaped, violet purple; very rich and sugary.

HUNGARIAN. Fruit very large, with tendency to come double; reddish violet, covered with a handsome bloom.

IMPERIAL EPINEUSE. Large and uniform in size. Very sweet, and of high flavor.

SUGAR. Skin very tender; at first of a light purple, tinted with green, changing at maturity to dark purple, covered with a thick, white bloom.

TRAGEDY. This is the earliest of all prunes, and earlier than any plum. Good size, dark purple skinl, yellowish green flesh. Sweet and very rich.

\section{NECTARINES}

4 to 6 feet, $65 \mathrm{c}$ each.

Boston. Rich flavor; excellent. July.

STANWICK. Very large, pale green skin shaded violet; flesh white; very tender, juicy and separates freely from the pit.

\section{APRICOTS}

Price, 4 to 5 feet, 65c each; $\$ 6.00$ per 10 .

BLENHEIM. The trees are early and regular bearers and have an abundance of foliage thoroughly protecting the fruit. Fruit above medium, oval; orange color; with deep yellow, juicy and rich flesh. July.

HEMSKIRKE. Large, roundish; flesh bright orange; tender and juicy, with a rich plum-like flavor; fruit not quite as large as the Noorpark, but ripens more evenly. August.

ROYAL. Of medium size, yellow with red cheek; immensely productive; an early ripening variety.

\section{ALIMONDS}

Price, 4 to 5 feet, 65c each; $\$ 6.00$ per 10 .

I. X. L. Nuts large; shells easily, no machine being needed, nor is any bleaching necessary; shell soft but perfect.

NE PLUS ULTRA. Tree a rapid grower, of bushy habit; a heavy and regular bearer.

NONPAREIL. Of a weeping style of growth; an extraordinary heavy and regular bearer, with very thin shell.

DRAKE'S SEEDLING. Very heavy and regular bearer; good to plant as a pollenizer: medium hard shell.

\section{QUINCES}

Price, 4 to 5 feet, 65c each.

APPLE, or Orange. Large, bright yellow.

CHAMPION. Very large; flesh tender, delicate flavor.

PINE APPLE. Very tender; makes a high flavored jelly; pineapple flavor.

\section{FIGS}

3 to 4 feet, $65 \mathrm{c}$ each; $\$ 6.00$ per 10.

CALIFORNIA BLACK. Large, tairk purple, almost black when fully ripe. (This variety does not require the Wild Fig for pollenization.)

WHITE ADRIATIC. One of the very best sorts.

KADOTA. One of the best for canning, preserving and pickling.

\section{ORANGES}

Price, lifted with balls of soil, $\$ 3.00$ each.

RIVERSIDE WASHINGTON NAVEL. Fruit first-class in every respect; symmetrical, seedless; pulp fine-grained.

VALENCIA LATE. An orange of remarkably strong-growing habit, and claimed by those fruiting it to be a good bearer; a little later than Mediterranean Sweet.

\section{LEIMONS}

\section{Price, lifted with balls of soil, $\$ 3.00$ each.}

EUREKA. Tree nearly thornless, of rapid growth and prolific bearer; fruit of the best quality. A general favorite.

LISBON. Medium size; sweet rind; very strong in acid; very few seeds; tree a rapid grower and very productive.

\section{POIIELOS (Grape Fruit)}

Price, lifted with balls of soil, $\$ 3.00$ each.

MARSH'S SEEDLESS. Medium, practically seedless; skin thin and smooth; pulp juicy; of superior flavor. Keeps late.

\section{OLIVES}

Mission. $1 / 2$ to $5 / 8$ inch caliper, $\$ 1.25$ each.

\section{GRAPES}

25c each; \$2.00 per 10.

FLAME TOKAY. A very fine large red grape.

MUSCAT OF ALEXANDRIA. Bunches and berries large, pale amber.

THOMPSON'S SEEDLESS. The well-known raisin grape; a fine eating variety.

ZINFANDEL. Another well-known sort.

\section{GRAPES (American Sorts) \\ 35c each; $\$ 3.00$ per 10.}

CONCORD. Berries large; color red; very sweet.

PIERCE. Berries black; heavy producer.

NIAGARA. Bunches large, very compact; greenish white in color.

\section{CURRANTS}

30c each; $\$ 2.50$ per 10.

CHERRY CURRANT. Very large, deep red. One of the best.

\section{GOOSEBERRIES}

OREGON CHAMPION. 30c each; $\$ 2.50$ per 10.

\section{RASPBERRIES}

CUTHBERT. The largest, handsomest and best red Raspberry cultivated. Bears transportation well. 15c each; $\$ 1.00$ per 10;\$6.00 per 100 .

GOLDEN QUEEN. Large clear yellow-amber berries. 20c each; $\$ 1.50$ per 10

ST. REGIS. of excellent quality; bears for a long period; berries large, bright crimson. 20c each; \$1.50 per 10. 


\section{FRUIT TREES AND SMALL FRUITS-Continued}

\section{BLACKBERRY HIMALAYA}

Bears immense crons of fruit, commencing to ripen about the middle of July and it will keep bearing until frost. The fruit is very large 'and the flavor is delicious, having a wonderfully fine aroma which commends itself to everyone.

1-year plants, 25c each; \$2.00 per 10.

\section{BLACKBERRY MAIMIOTH}

Named by some "The Black Loganberry."

Flavor is a decided improvement on any known variety of blackberry. Set out nine feet apart, and six feet in the rows. 1-year plants, 25c each; \$2.00 per 10.

\section{THE LOGANBERRY \\ (Raspberry-Blackberry)}

It partakes of both flavors of the raspberry and the blackberry, being a combination of the two mixed; a very pleasant, mild, vinous flavor. 1-year plants, 25c each; \$2.00 per 10.

\section{CORY THORNLESS BLACKBERRY}

The berries often measure $21 / 2$ inches in length, have a small core and are almost seedless. The flavor is like the wild berry, but they are richer and sweeter than other blackberries, yet are acid enough to make the finest of jelly.

They are very early and bear enormously through a long season. $30 \mathrm{c}$ each; $\$ 2.50$ per 10 .

\section{PHENOMENAL BERRY \\ 30c each; \$2.50 per 10.}

\section{STRAWBERRIES}

Price, 35c per 12; \$2.50 per 100.

BRANDYWINE. (Per.). Very productive; blossoms perfect; fruit very large, of good form, bright red all over, and of good quality. Season, medium to very late.
KLONDYKE. Rich red; of mild flavor; quite juicy; very productive.

MAGOON. Large berry, dark red in color, and of very fine aroma.

MARSHALL. (Per.). Of enormous size, blood red color, rich aromatic flavor. One of the good old "standbys."

OREGON EVERBEARING. A very fine variety; a heavy and regular bearer.

\section{BANNER STRAWBERRY}

This well-known variety is now so well known that it needs no description; excellent in every way. $35 \mathrm{c}$ per $12 ; \$ 2.50$ per 100.

\section{WALNUTS}

FRANQUETTE. Grafted on California Black. 4 to 5 feet, $\$ 1.50$ each; $\$ 13.50$ per 10.

MAYETTE. Grafted on California Black root. 4 to 5 feet, $\$ 1.50$ each; $\$ 13.50$ per 10.

\section{LAWTON BLACKBERRY}

This variety produces large, luscious berries; this variety does not vine, but is of bush habit. 15c each; \$1.25 per 12.

\section{ASPARAGUS ROOTS $\$ 2.50$ per 100 .}

\section{HORSE RADISH ROOTS}

50 c per 12; \$2.50 per 100 .

\section{RHUBARB ROOTS \\ 25c each; \$2.00 per 12.}

Kindly let us know if we can substitute, should we be sold out of any of the varieties ordered. Special prices on fruit trees, in larger quantities than we have specified, will be given on application.

\section{DISTANCES FOR PLANTING FRUIT TREES}

Standard Apples..................................25 to 30 feet apart each way Standard Pears .24 to 30 feet apart each way Cherries ...................................24 to 30 feet apart each was Standard Plums and Prunes................24 to 30 feet apart each way Apricots, Peaches, Nectarines............24 to 30 feet apart each way Grapes ........................................ 7 to 10 feet apart each way Walnuts ..........................................40 to 50 feet apart each way Currants and Gooseberries.........................................................4 by 6 Blackberries and Loganberries..................................3 to 4 by 5 to 7
Strawberries for Field Culture.. 1 to $1 \frac{1}{2}$ by 4 to 5 to 2 feet apart

To find out how many trees it takes to plant one acre-Multiply the distance in feet between the rows by the distance the plants are apart in the rows, and the product will be the number of square feet for each plant or hill, which, divided into the number of feet in an acre $(43,560)$, will give the number of plants or trees to the acre.

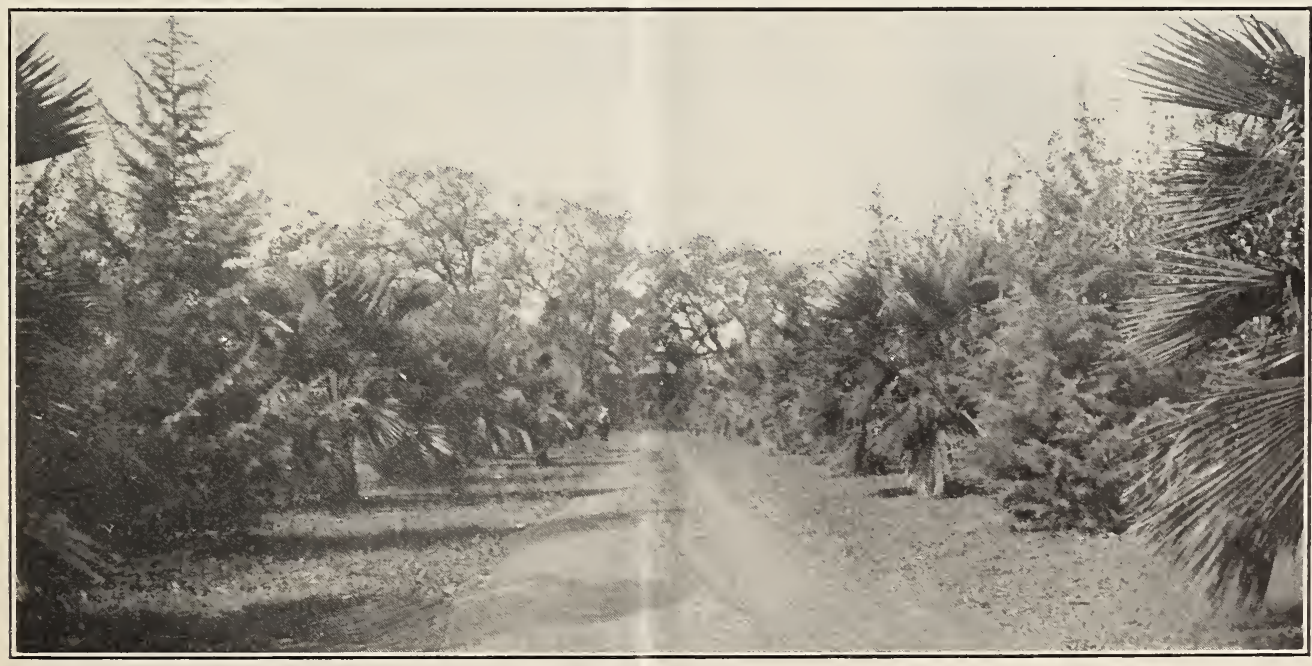

Avenue of Palms and Cedars at our San Jose Orchard 


\section{KINDLY READ THE FOLLOWING}

\section{LITTLE ARTICLE}

The months of November to April are ideal for the setting out of evergreen trees and shrubs; many homes are now made beautiful by the intelligent planting of these; they add so much to the home, and the cost is so reasonable that not a house should be without this adornment. In order to further this laudable work, we take pleasure in offering a few suggestions. The larger percentage of homes now being built are medium in size and therefore it does not require a large expenditure of money.

For the average requirements we think the following list will be found about right: The. Italian Cypress or the Arizona Blue Cypress will be what you will require for pyramid shaped plants; the Abelia, a very fine variety having pinkish-white flowers in clusters; Berberis Darwini, foliage small, glossy green, flowers yellow; Coprosma, sometimes called "Mirror Plant" on account of its very glossy leaves which shine as though varnished; the Cotoneasters and Crataegus are those shrubs which bear such lovely red and orange colored berries in the fall and winter months; Diosma ("Breath of Heaven") is a lovely low growing shrub bearing small white flowers, the foliage when pressed in the fingers emits a sweet odor; the Heathers produce small bell-shaped flowers in great profusion and are much admired; Genista Racemosus belongs to the Broom family, is of rather dwarf habit, flowers in long racemes of striking yellow; the Spanish Broom is another favorite, this variety is larger growing than the preceding and has canary yellow flowers borne in great profusion during summer and fall months; Lonicera Nitida is another shrub we can recommend, it is of quick growth, and has small glossy leaves, can be trimmed like a boxwood if so desired; Pittosporum Crassifolia you will fall in love with, the underside of the leaves are sea-green in color, it bears seed pods which when ripe burst open and show the red seeds, perhaps you have noticed this shrub and wondered what it was, you should have one of these by all means; Oregon
Grape (Mahonia), lovely glossy holly-like foliage; the Pink Crepe Myrtle you very likely are acquainted with, one does not see many in this vicinity, but in valleys they are wonderful. Why not plant some Fuchsias? Your garden would not be complete without them; take the Baby Fuchsia, for instance; don't you think they are charming? The Laurustinus is also good, flowers very showy; the English Myrtle must also be remembered, leaves dart shaped, small and shiny, and when bruised emit a pleasant aromatic odor, flowers white in clusters. The different species of Veronicas are much used in beautifying of homes; the flowers are of various shades of blue, and one variety has ruby colored flowers; there are also three low growing kinds that are of dwarf habit, Cupressoides, Buxifolia and Traversii; they grow like Boxwoods, but more satisfactory, we think; if you have any little spaces on the walks to your house, use either of these.

How about a nice border? Would you care to have one? then use the Dwarf Boxwood; this never grows very high, foliage nice pleasing green. If you don't care for this then try the Santolina, foliage sage green; requires trimming about twice a year. The Sea Pink (Armeria) is good for edging and has pretty pink flowers. Feverfeu (Golden Feather) of course you know, as it is much used for borders.

Would you care to have some trees on your sidewalk? If so, get neighbors together and agree upon one variety; a conglomeration of varieties on the sidewalk is heart-breaking and should not be allowed. The Black Acacia and Acacia Latifolia are ideal for this purpose; these two varieties can be trimmed to suit. Some people like the Purple Leaved Plum, very nice, and some use the Hawthorn for sidewalk, but to our way of thinking, the sidewalk is no place for it; it is all right in some place in the back garden where you can go and visit it on a nice dewy morning, when in bloom, and the sweet fragrance will carry you back to the days of your youth. Oh! don't forget the Silver Birch and Mountain Ash; they are very dear to us all.

Fuller descriptions and prices will be found on pages 5, 6 and 7 of this booklet.

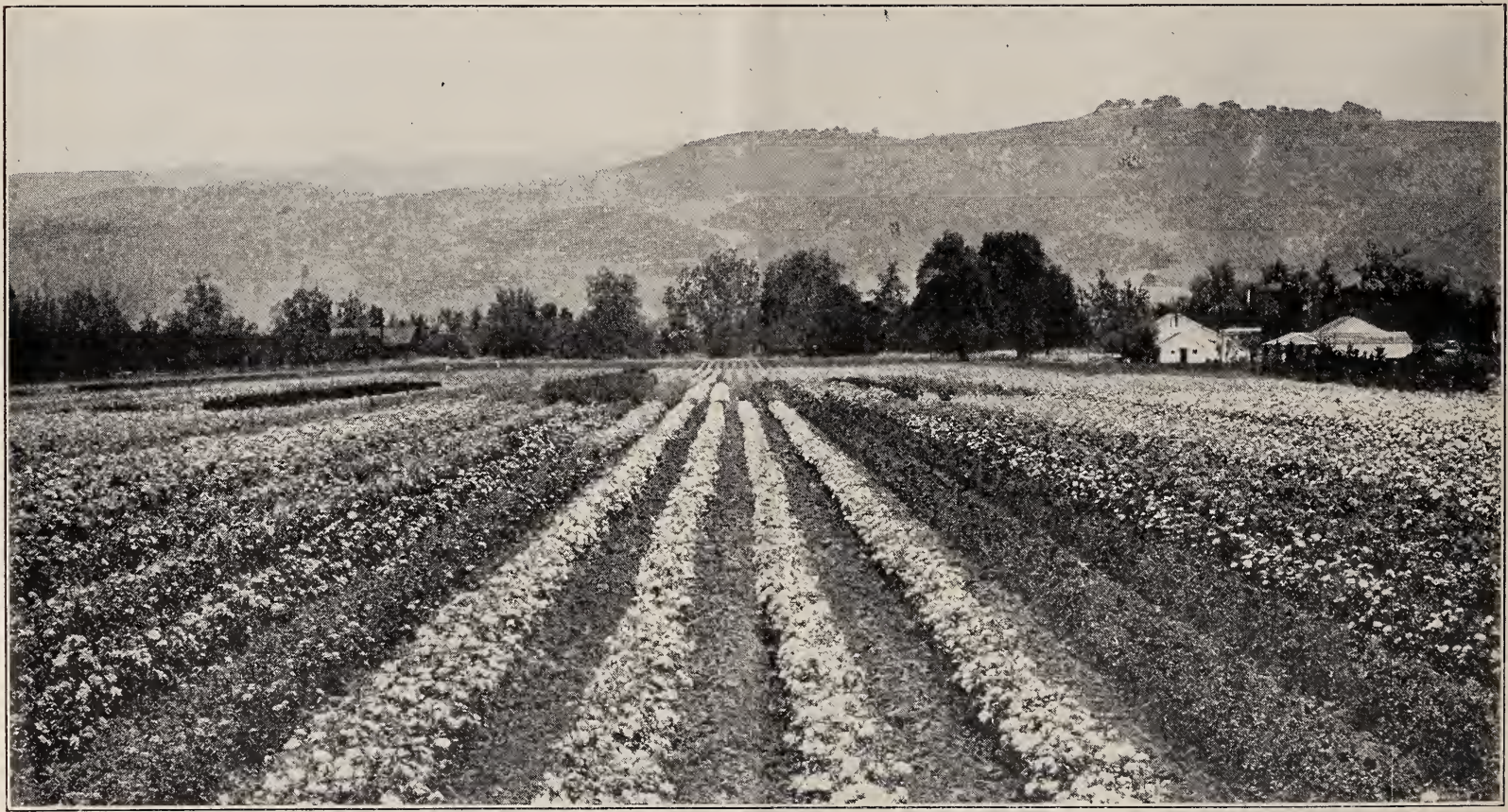

Field of Roses. Note wealth of bloom and size of plants.

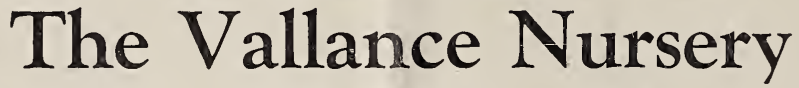

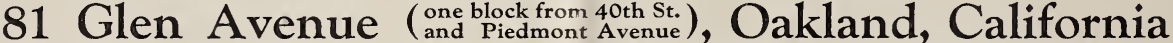

We are succeeding the Nursery department of C. C. Morse \& Co., and are continuing the business at the old location, 81 Glen Avenue, just one block from 40th Street and Piedmont Avenue. Prospective customers and those interested in plants are invited to call and inspect our stock and consult us about planting at all times.

Our experience in planting Ornamental Grounds and Orchards, extends actively over 25 years in California.

We are glad to consult with you about your planting problems.

THE VALLANCE NURSERY give no warranty, express or implied, as to description, purity, productiveness, or any other matany plants or trees they send out, and will be in no way responsible for the crop. If the purchaser does not accept the in these ternis they are at nnce to be returned. 